\title{
Rare-metal granites as a potential source of critical metals: a geometallurgical case study
}

\author{
Quentin DEHAINE ${ }^{1,2, *}$, Lev O. FILIPPOV ${ }^{1}$, Hylke J. GLASS² and Gavyn ROLLINSON² \\ ${ }^{1}$ GeoRessources, Université de Lorraine, CNRS, UMR 7359, 2 rue du Doyen Marcel Roubault, TSA 70605, F54518, \\ Vandœuvre-lès-Nancy, France \\ ${ }^{2}$ University of Exeter, Camborne School of Mines, Penryn, Cornwall, TR10 9FE, United Kingdom \\ *Corresponding author: Q.Dehaine@exeter.ac.uk \\ Phone: +44 (0) 1326253602
}

\begin{abstract}
Because of their low grades in critical metals such as Light Rare Earth Elements (LREE) or Sn, rare-metal granites are not considered as economic for metal recovery but, when altered, they are often exploited for their industrial minerals. The St Austell rare-metal granite is well known for its world-class kaolin deposits which formed as a result of the extensive weathering and alteration of the underlying granite. The St Austell granite body is composed of several granite components, each having its own accessory minerals assemblage. As a result of the kaolinisation process, some metal-bearing accessory minerals of the granite, such as monazite (LREE) or cassiterite (Sn), are partially liberated from the gangue which allow their pre-concentration in the micaceous residue which is considered as a potential source for critical metals recovery. A geometallurgical approach is fundamental for this unconventional 'resource', not only because of its nature but also because the target metals must be considered as by-products. Similarities with other similar rare-metal granites suggest that topaz granite is the most prospective for disseminated magmatic Sn-Nb-Ta-REE mineralization. However, comparison of the potentiality of 3 granite types i.e. biotite, topaz and tourmaline granites suggest that biotite granites is actually the most prospective due to higher degree of kaolinisation of the biotite granite which favour pre-concentration of its accessory mineral in the micaceous residue. In order to develop a geometallurgical framework for extraction of kaolin and metals from the selected granite component, a field sampling campaign is performed. Core samples are processed in the laboratory using a characterisation program that mimics the full-scale kaolin refining route. Two main products are recovered through this program, viz. GT53ㅆ $180(-180+53 \mu \mathrm{m})$ and $\mathrm{R} 5 \underline{\mathrm{P} 5}(-5 \mu \mathrm{m})$, which correspond to a fine micaceous residue and a fine kaolin product respectively. These products are both analysed routinely for major and minor trace elements by XRF and yields are recorded to indicate process performance. A selected number of GT53MR180 samples are also being characterised in terms of particle size by laser light scattering, geochemistry by ICP-MS, and mineralogy by QEMSCAN ${ }^{\circledR}$. Comparison of characterisation results of GT53MR180 samples and corresponding industrial residue samples shows a good correlation, suggesting that sample analyses are representative for the in-situ deposit and the processing behaviour. Monazite is found to be either fully liberated or fully locked from one sample to the other. Next, pilot-scale gravity concentration tests are performed on micaceous residue samples. Characterisation of the processing products shows that monazite lost in the tailings is mostly locked within tourmaline or micas and is fine grained. Then, predictive regression models for spiral separation performance in terms of recovery, product grade and enrichment as a function of the feed grade are developed for GT53MR180 LREE grade data. Finally, kaolin resources can be classified using quantitative indicators such as yield of the R5P5 product and the iron oxides content which provides insight into the kaolin quality in terms of whiteness. This geometallurgical classification can be used to delineate zones of interest within the deposit. Although kaolin quality and recovery primarily inform extraction planning, zones which are also of interest for metal recovery can be identified. The proposed model predicts whether the expected LREE grade and recovery satisfy the by-product requirements.
\end{abstract}

Key words: kaolin residue, Light Rare Earths, critical metals, rare-metal granites, geometallurgy, QEMSCAN ${ }^{\circledR}$. 
Ensuring sustainability all along the raw materials value chain has been a growing concern for the extractive industry in recent years. While more efficient recycling of materials will be achieved in the foreseeable future, as depicted by the concept of circular economy, recycling of some materials suffers practical limitations which are not exempt from natural resources extraction with regards to our growing societal needs. This is particularly true when it comes to critical metals which have a low recycling rate and for which there is no substitute. These critical metals have been highlighted by a recent initiative by the European Commission defining the criticality of a material based on three main indicators, i.e. the supply risk, the economic importance and the environmental country risk. A list of 14 economically important Critical Raw Materials (CRMs) was published in 2010, recently extended to 20 (European Commission, 2014) which include Niobium (Nb) and the Light Rare Earth Elements (LREEs). For some of these metals, mined as by-product, the availability is also conditioned by the major metal of the ore in which they occurred usually in low concentration (Mudd et al., 2016). Rare Earth Elements (REEs) for instance, are mainly recovered as co-products/by-products of certain other minerals in many mining operations (Kumari et al., 2015). As of 2018, there are no more active mines in the western world operated exclusively for the recovery of Rare Earths. REE projects outside China, which re-opened or opened after the 2011 spike in REE prices, such as the Mountain Pass mine and the Bear Lodge deposit (United States), or the Mount Weld mine (Australia), have all sustained or suspended their production or development due to relatively low REE prices (Imholte et al., 2018). This situation has stimulated other countries to look for alternative REE resources and to develop their own REE industry, in particular by looking into recycling of REE from End-of-Life products. However, much less attention has been paid to historical landfilled stocks and freshly produced flows of REE-containing industrial process residues which usually present much lower REE concentrations but are present in very large volumes (Binnemans et al., 2013). Total amounts of REE locked in these residues are also very large and may secure an independent source of REE as well as shielding resource-poor countries from export quotas and price fluctuations (Binnemans et al., 2015). Industrial mineral wastes, such as those from the kaolin industry in Cornwall, UK, have proven to be a potential source for REE, $\mathrm{Sn}$ and $\mathrm{Nb}$ recovery (Dehaine et al., 2017; Dehaine and Filippov, 2015a; Filippov et al., 2016; Scott et al., 1998). The kaolin 
deposits are formed by weathering and alteration of granite rocks. As a consequence of the kaolinisation process, accessory minerals of the granite are partially liberated from the gangue. Hence, during refining of kaolin ore, spontaneous pre-concentration of the metal-bearing accessory minerals, such as monazite hosting LREE (i.e., cerium (Ce), lanthanum (La) and neodymium (Nd)), cassiterite hosting Sn or rutile hosting $\mathrm{Nb}$, occurs in the micaceous residue (Dehaine and Filippov, 2015a).

In order to convert such an unconventional resource into a potential REE resource, development of innovative technologies and geometallurgical approachesan integrated approach to mine value chain optimisation are is required on a strategic and tactical level. Geometallurgy is a discipline that seeks to reduce technical risks through advanced ore characterisation which allows maximisation of resource efficiency and minimisation of energy consumption and waste generation. This could be expressed in the creation of a spatial predictive model which informs optimal extraction, processing and waste disposal. combines geological and metallurgical information to create a spatially based predictive model for mineral processing plants in order to reduce technical risk (Lamberg, 2011). This aims to document The predictive model accounts for variability within the orebody -within the orebody and quantify the impact of-some geological, mineralogical, chemical and geotechnical factors that impacten metallurgical processes (grinding, recovery) through -in order to classify the resources in geometallurgical domains (Cabri et al., 2017). The datase thus generated can be realily integrated into a 3D model (Williams and Richardson, 2004). Thus, it is necessary to develop simple and effective characterisation methods of the distinct processing products/residues. This is particularly true when it comes to industrial minerals such as kaolin for which the final product is a mineral concentrate rather than a mono-element product (Glass, 2016). Geometallurgy can be broadly split into two key levels: strategic geometallurgy, which focuses on the whole orebody and long-term life-of-mine scale and tactical geometallurgy which relates to the short- to medium-term scale during daily operation (McKay et al., 2016).

Such a strategicn approach is fundamental for the unconventional 'resource' investigated in this feasibility work, not only because of its nature but also because the target metals must be considered as by-products. Applying a geometallurgical approach to this case study is rather challenging for several reasons. First, there are no a priori certainties on the economic feasibility of metal by-product recovery 
111 and there are no known specifications for a marketable product consisting of REE. Next, if the operation

112 is already in production, there is no processing on site for metal recovery from micaceous residues. This

113 influences the development of a hypothetical geometallurgical model: most geometallurgical programs are applied to more conventional deposits already in operation for which a significant amountthere is no historical process-of data are available, with large numbers ofnor a geometallurgical variables-database allowing the use of multivariate modelling (Boisvert et al., 2013). Finally, given the complexity of the investigated deposits, with multiple granite-types each one having its own accessory mineral assemblage, this approach could not consider the whole St Austell granite but will have to focus on a specific granite type, ore-type or location. The representativeness of the results that will be obtained is also a key feature for a potential application_-Hence, there is a need to develop performance prediction models to evaluate process efficiency and product characteristics (metal grades and recovery) therefore assessing the critical metals by-product potentiality. The proposed approach applied to a typical kaolinised rare-metal granite seek to feed the initial strategic/feasibility work on similar deposit with the objective of supporting tactical geometallurgy during kaolin production. metals (Manning and Hill, 1990), and for its current international importance as a major kaolin producer. the multi-scale spatial relationship between Variscan granites and Sn-W deposits from the Variscan belt to the St Austell district. The major tin belt passes from the Cornubian massif (Redruth, Camborne, etc.) in UK through the French Massif Central (Echassières) and continues towards Italy with tertiary tin deposits (Elbe, Tuscany and Scilly). Other tin belts are also related to Variscan granites, like the one which pass from Northern Portugal (Panasqueira) through Spain or the one around the Bohemian massif (Cinovec-Altenberg). Most of these tin deposits are associated with Sn-W cupolas located at the top of 
tardi- to post-orogenic plutons emplace at shallow depths (Jébrak and Marcoux, 2008).

The batholith of SW England was formed during the late Variscan orogeny in the Late Carboniferous to Early Permian (270-300 Ma) intruding deformed Devonian-Carboniferous terrestrial to marine sediments. The batholith has a 200-km-long extension (Willis-Richards and Jackson, 1989), comprising six major and several minors granite bodies. The major bodies, from east to west, are Dartmoor, Bodmin Moor, St Austell, Carnmenellis, Land's End and the Scilly Isles (Figure 1Figure 1b).

The outcrops are dominated by biotite-bearing monzogranite, with minor intrusions of tourmalinebearing aplites, pegmatites and local fine-grained facies (Manning et al., 1996). In addition, there are some occurrences of other granite types, resulting from multiple intrusive episodes, such as the lithiummica granites or the topaz-bearing granite in the Tregonning-Godolphin Granite, and the St Austell Granite (Manning et al., 1996; Manning and Exley, 1984; Manning and Hill, 1990). The batholith was affected by several episodes of alteration including quartz-tourmaline veining associated with greisening, intrusion of rhyolite dykes, quartz-hematite veining. Kaolinisation is the last alteration event, which is believed to have a meteoric origin (Psyrillos et al., 1998; Sheppard, 1977), and was relatively extensive in the western part of the St Austell pluton where the majority of the active kaolin pits are located (Figure 1Figure 1b).

According to Willis-Richards \& Jackson (1989) there is a close spatial association between the batholith and the rich $\mathrm{Sn}, \mathrm{Cu}$ mineralisation of the Cornubian Peninsula. Most of the ores of $\mathrm{Sn}, \mathrm{Cu}, \mathrm{W}$, $\mathrm{Zn}$ and As came from vein deposit type mineralisation, along or parallel to the axis of the batholith (Moon, 2010). Within the St Austell granite, zones of intense kaolinisation are spatially related to swarms of steeply dipping, quartz-tourmaline \pm cassiterite \pm wolframite sheeted veins with greisen (quartz-muscovite-tourmaline \pm topaz \pm wolframite) alteration selvages, observable at Goonbarrow pit (Bray and Spooner, 1983). These mineral lodes are located South, North, or to a lesser extent within the St Austell granite kaolinised area (Figure 1Figure 1c and Figure 2Figure 2).

\subsection{The St Austell rare-metal granite}

Rare-metal granites are so-called because of their mineralisations being disseminated through the granites rather than concentrated in layers, lodes, etc. The St Austell rare-metal granite share numerous 
characteristics with other granites of SW England, summarised in many reference papers and textbooks (Floyd et al., 1993; Manning, 1996; Manning and Hill, 1990). These granites were originally described by four different granite types, all observed in distinct SW England granites: biotite granite, lithium mica granite, the tourmaline granites and topaz granite (Hill and Manning, 1987). Additional granite type were added later based on field and textural observations within the St Austell granite, indicating complex late-stage magmatic and hydrothermal processes (Manning et al., 1996). The St Austell raremetal granite is composed of six major granite types, each unit being characterised by a specific mineral assemblage and textures (Manning et al., 1996), see Figure 2Figure 2.

The biotite granite (BG) is the main lithology, which represent up to $70 \%$ of the outcrop of the St Austell granite, exposed in the Western Area, at the eastern part of the pluton and intermittently within the Central Area. It corresponds to the megacrystic biotite granite observed at Land's End and Dartmoor granites (Manning et al., 1996; Manning and Exley, 1984), see Figure 1Figure 1b. It is coarse grained, mainly composed of quartz, $\mathrm{K}$-feldspar and micas with tourmaline and topaz as minor phases. Biotite is the main mica, but muscovite is also present. The main accessory phases have been reported as rutile, topaz, apatite, monazite, cassiterite, zircon and uraninite (Manning et al., 1996). The main host for the LREE differs depending on the authors. Works of Jefferies, (1985) on Carnmenellis biotite granite describe monazite as the main LREE-bearing mineral accounting for approximately $75 \%$ of the total LREE content. In contrast microprobe analyses on samples from Cornubian granites by Alderton et al. (1980) show significant concentrations (up to $0.5 \%$ ) of $\mathrm{La}, \mathrm{Ce}, \mathrm{Nd}$ and $\mathrm{Sm}$ in other phases, particularly apatite, but also zircon and titanite.

The lithium mica granite (LMG) has a similar grain size and texture to the biotite granite (Manning et al., 1996). It is characterised by the presence of lithium mica (zinnwaldite) and plagioclase (albite component). The accessory minerals are present as inclusion in zinnwaldite (apatite, monazite, zircon and rutile) or in plagioclase (apatite, fluorite and secondary micas).

The tourmaline granites were subdivided by Manning et al. (1996) in a Tourmaline granite (TG), itself regrouping a globular quartz and medium coarse-grained equigranular facies, and in a fine-grained tourmaline granite (FGTG) with fine-grained $(<0.5 \mathrm{~mm})$ equigranular facies. The globular quartz facies is characterised by a considerable textural variation. It contains large quartz grains, phenocrysts of 
micropethite, zinnwaldite with a fine-grained groundmass of quartz, K-feldspar, plagioclase, zinnwaldite, tourmaline and topaz. The accessory phases are limited to apatite and rutile. On the other hand, the fine-grained facies is an equigranular rock with euhedral albite and zinnwaldite. Accessory minerals include monazite, apatite, zircon and rutile with some occurrences of arsenopyrite and cassiterite.

The topaz granite (TZG) is medium-grained, characterised by euhedral-subhedral fluorine-rich topaz, interstitial lithium mica, albite, plagioclase feldspar with perthitic orthoclase, and subhedral quartz (Manning and Hill, 1990). It contains a smaller proportion of accessory phase but a wider variety including sub-economic minerals (Manning et al., 1996). The accessory minerals are apatite, amblygonite $\left(\mathrm{LiAlPO}_{4} \mathrm{~F}\right)$, zircon, $\mathrm{Nb}$-Ta oxides (columbite-tantalite and ilmenorutile) and uraninite. The mineralogy of the six granites is summarised in Table 1Fable 1.

Apart from these magmatic disseminated mineralisations, Sn-W mineralisations associated with quartz-tourmaline sheeted veins previously described, are also present within the St Austell granite (Bray and Spooner, 1983). Whereas two different types of mineralisations, a Sn breccia-stockwork in the Treliver area, generally unenriched in base metals, and a E-W veins complex enriched in base metals have been identified north of the St Austell pluton (Camm and Dominy, 1999; Camm and Moon, 2001). In addition, Müller and Halls (2005) describe an intrusive tourmaline breccia in biotite granite at Wheal Remfry where zoned rutile is the main host mineral for Sn (up to $1.88 \%$ ) and exhibits high W (up to $1.95 \%$ ) and $\mathrm{Nb}$ (up to $2.05 \%$ ) domains.

\subsection{Similarities with rare-metal granites worldwide}

The spatial relationship between critical metals mineralisations and Variscan granites previously discussed is confirmed by the numerous similarities between the St Austell rare-metal granite and several rare-metal granites worldwide. From all the magmatic units of the St Austell pluton, the topaz granite is the youngest, and the most geochemically different, relatively enriched in $\mathrm{Li}, \mathrm{Rb}$ and with a much higher $\mathrm{Nb} / \mathrm{Zr}$ ratio (Manning and Hill, 1990). Nonetheless, there are close similarities between the mineralogical assemblages described above and the accessory minerals assemblage of evolved granite elsewhere described as peraluminous high to intermediate phosphorus granites (Linnen and Cuney, 
2005; Simons et al., 2017). All the St Austell granite types are felsic, weakly peraluminous granites (Manning et al., 1996). The comparison of the $\mathrm{P}_{2} \mathrm{O}_{5} / \mathrm{SiO}_{2}$ ratio of the St Austell granites with other raremetal granites show that the St Austell granites belong to the intermediate phosphorous granite (IHP) type (Figure 3Figure 3). The relatively low $\mathrm{Zr}$ and Th contents of St Austell granites, visible in Figure 3Figure $3 \mathrm{~b}$ are characteristic of non-peralkaline rare-metal granites (Linnen and Cuney, 2005).

These granites are formed in a late-orogenic context and associated with orogenic belts (Figure 1Figure 1b) and are usually characterised by highly differentiated leucocratic two-micas granites, corresponding to the S-type, rich in hydroxylated minerals (muscovite) and enriched in lithophile elements such as Nb, Ta, Li, Be, P , F (Jébrak and Marcoux, 2008). Among these granites some display similarities with the St Austell granite and are associated with $\mathrm{Sn}, \mathrm{W}$, and $\mathrm{Ta}-\mathrm{Nb}$ disseminated mineralisations (Černý et al., 2005). Some of this granites are associated to kaolin deposits which are also known to display similarities with Cornish kaolin deposits (Wilson et al., 1997; Wilson and Jiranek, 1995).

According to Scott et al., (1998), the Yichun granite in China is one of the closest rare-metal granite, in terms of lithology. It comprises also several magmatic units including a biotite granite and a Li-mica (lepidolite) granite such as the St Austell granite. The Li-micas granite is the most evolved magmatic unit and display a similar accessory assemblage of amblygonite/montrebasite, apatite, fluorite, Mntantalite, microlite, Ta-cassiterite, ilmenite, monazite, zircon, sphalerite and topaz (Belkasmi et al., 2000; Yin et al., 1995). The Beauvoir topaz-lepidolite albite granite (Massif Central, France) is also very similar to the St Austell topaz granite and display a Sn-Li-Ta-Nb-Be disseminated mineralisation with an accessory minerals assemblage composed of topaz, apatite, amblygonite, columbite-tantalite, microlite, zircon, uraninite and sphalerite (Cuney et al., 1992; Raimbault et al., 1995). Further similarities exist with the Podlesí granite in Czech Republic which is composed of three magmatic units, including biotite granite, and two Li-mica granites. All granite type contain disseminated Ta-Nb-Ti-WSn minerals including rutile, cassiterite, Fe-columbite, ixiolite and ferberite (Breiter et al., 2007). The Younger Granites province of Nigeria displays also some similarities with the above-cited rare-metal granite complexes, especially the subalkaline granites which are mineralised with rich deposits of cassiterite, columbite, sphalerite, wolframite and galena and are the primary source of alluvial cassiterite 
and columbite mineralisation (Ogunleye et al., 2006).

By analogy with the Beauvoir granite it is possible to suggest the most prospective granite type within the St Austell pluton for disseminated magmatic mineralisation. Rare-element chemistry of the Beauvoir granite shows that the concentration of most metallic elements including $\mathrm{Nb}, \mathrm{Ta}, \mathrm{Sn}$ and $\mathrm{W}$ increases with the Li contents from the bottom to the upper part of the granite body (Cuney et al., 1992). As discussed above, the St Austell topaz granite exhibits the greatest enrichment in $\mathrm{Li}$ and is petrogenetically distinct from other granite types (Manning and Hill, 1990) with mineralogical and geochemical characteristics matching closely those of other rare metal granite worldwide. Thus, the St Austell topaz granite is considered to be the most prospective for REE and Sn-Nb-Ta mineralisation. The top of the Beauvoir Granite cupola is the most enriched part of the orebody in terms of rare-metals due to a combination of magmatic process and interaction with meteoric water (Raimbault et al., 1995). It is therefore the upper parts of the topaz granite that should have the greatest potential for disseminated magmatic mineralization. The exact morphology and the intern organisation of the topaz granite is poorly constrained but Manning and Hill (1990) suggested that the individual outcrops of topaz granite may be connected at depth. The field relations indicate that the Nanpean stock represents a position well below the roof of the granite body and that the Hensbarrow stock represents the roof. Thus, from a pure metallogenic perspective, the Hensbarrow stock, which represents the upper part of the St Austell topaz granite, is the most prospective for REE and $\mathrm{Sn}-\mathrm{Nb}-\mathrm{Ta}$ magmatic mineralisations.

\section{ST AUSTELL KAOLIN OPERATIONS}

China clay, also called kaolin, is a commercial clay material mainly composed of kaolinite $\left(\mathrm{Al}_{2} \mathrm{Si}_{2} \mathrm{O}_{5}(\mathrm{OH})_{4}\right)$, a hydrated aluminosilicate clay mineral. Its main uses are for coating and filling in paper industry ( $75 \%$ of world's production), the ceramics industry but it has also a wide variety of speciality uses, i.e. for plastics, ink, paint, rubber, and pharmaceutical industry. The composition of the granites has a significant influence on the quality of the kaolin ore (Scott et al., 2002). The commercial value of a kaolin product is based on its whiteness and its fine particle size. Particle size affects fluidity, 
flat particle shape, which increases opacity or hiding power, its soft and non-abrasive texture, due to the absence of coarser impurities, and its chemical inertness (Highley et al., 2009).

The UK is one of the world's largest producers and exporters of kaolin, after the USA, Brazil and China, supplying up to 1.36 million dry tonnes of clay per annum, in 2008 for the paper, ceramics, paints, plastics and rubber industries (Highley et al., 2009). Production is supplied from a large number of open pits scattered throughout the western part of the granite outcrop within a complex landscape of spoil heaps and mica lagoons as shown in Figure 2Figure 2. Kaolinite is a secondary mineral formed by weathering and hydrothermal alteration of the alumina silicates of host rock, mostly feldspar minerals, by acid aqueous fluids to form an aggregate of kaolinite and secondary micas.

Kaolin extraction has traditionally been done by hydraulic mining in which high-pressure jets of water are used to disaggregate the weak, kaolinised granite and disperse the kaolinite particles, together with the other components of the granite, into a slurry, leaving behind the less well decomposed material in the form of coarse sand and gravel, locally called "stent". The resulting "clay stream" flows into the pit sink and is then pumped to the in-pit processing loop More recently, 'dry' mining has been introduced, allowing more selective extraction and improving yields (Highley et al., 2009). The plant is fed with clay matrix transported directly from the pit by cut and carry operations without any washing. Hence, the material fed into the plant is much coarser and more classification stages are required to remove the coarsest materials (Ano, 2008). The first stages of kaolin ore processing consist of removing the coarsest fractions of the clay matrix which are not valuable for kaolin recovery. Thus, the kaolin refining plant can be seen as a classification process producing different size classified wastes and a fine kaolin product (Figure 4Figure 4). The first sized-classified wastes i.e. crushed stones $(-21+11 \mathrm{~cm})$, gravels $(-110+8 \mathrm{~mm})$ and sands $(-8+0.5 \mathrm{~mm})$, are removed by screening and are sent to stockpiles. The last classification stage is realised by series of hydrocyclones. The finer particles (overflow) go to the product stream for further refining whereas the coarser particles (underflow) are reported to the micaceous residue where they are held in suspension and pumped to a tailing dam. Additional techniques are used to improve the brightness (whiteness) and particle size of specific grades of clay. These include blending, fine grinding, chemical reductive bleaching and/or the removal of iron-bearing impurities using magnetic separation. Some kaolin products are also calcined at specific temperatures to give 
different products.

The gravity processing route presented in Figure 4Figure 4 corresponds to an hypothetical critical metal by-product recovery route which have been tested on pilot-scale and described in Dehaine (2016). It starts by a screening of the micaceous residue to remove the coarser fraction $(+180 \mu \mathrm{m})$, which is not treated, and preparation of the feed for the gravity concentration $(-180+53 \mu \mathrm{m})$ and flotation routes $(-53$ $\mu \mathrm{m})$. The proposed gravity concentration route comprise one spiral concentration step followed by a refining of the spiral concentrate by shaking table concentration. For details about the flotation route see Dehaine (2016) and Filippov et al. (2016).

\subsection{Core samples}

\section{MATERIALS AND METHODS}

All the core sample data used in this work are from a sonic drilling campaign undertaken in 2011 by Imerys Minerals Ltd, UK. The dataset selected for this study covers only the Melbur-Virginia and Wheal Remfry pits (referred as pit A and pit B hereafter) located at the western part of the St Austell granite (see Figure 2Figure 2) and comprise around 1200 core sample collected every 3 meters over 100 drill holes.

\subsubsection{Core samples processing protocol}

The main objective of this sampling campaign was to assess kaolin resources and alternatively critical metals resources, in terms of yields and chemical composition of the potential end-products through a laboratory-scale sample processing program that mimics the full-scale kaolin refining route (Figure 5Figure 5). Samples-The whole core samples were crushed to $15 \mathrm{~mm}$ if required (50 $\mathrm{mm}$ top size) in a jaw-crusher and then stirred/mixed with water to liberate any kaolin from the kaolinised granite. At this stage, the obtained material is equivalent to the output of the washing barrel of the plant (stream 5, Figure 4Figure 4). The slurry is then classified on a vibrating $180 \mu \mathrm{m}$ screen as with the classification stages realised by the bucket-wheel de-sander/ $660 \mathrm{~mm}$ cyclones to obtain a $-180 \mu \mathrm{m}$ material (stream 12, Figure 4Figure 4). This is followed by a screening of the $-180 \mu \mathrm{m}$ material on a vibrating $53 \mu \mathrm{m}$ screen as performed in the full-scale plant by primary cyclones. The $-53 \mu \mathrm{m}$ material 
is then treated to remove the $-53+15 \mu \mathrm{m}$ material by sedimentation. If required, a magnetic separation was then applied to the $-15 \mu \mathrm{m}$ material to improve brightness/colour as applied in the refining stages of the industrial process. Finally, the $-15+5 \mu \mathrm{m}$ fractions are removed by sedimentation and a $-5 \mu \mathrm{m}$ 336 high quality kaolin product is recovered. In the end 3 products are recovered, viz. GT53-MR180 ($180+53 \mu \mathrm{m}), \mathrm{R} 15-\underline{\mathrm{P} 15}(-15+5 \mu \mathrm{m})$ and $\mathrm{R} 5 \underline{\mathrm{P} 5}(-5 \mu \mathrm{m})$ corresponding to the $-180+53 \mu \mathrm{m}$ fraction of the micaceous residue fed to the gravity concentration route (stream 23 , Figure 4Figure 4$)$, a rough $(-15 \mu \mathrm{m})$ kaolin product and a fine $(-5 \mu \mathrm{m})$ kaolin product (stream 16, Figure 4Figure 4), respectively. Each product is weighed at each step of the process, so that the yield of each product is known. All the final products were then analysed by X-Ray fluorescence (XRF) for major elements whereas ProTrace XRF analyses (analyses for trace elements) were only carried out on the $-180+53 \mu \mathrm{m}$ (GT53ㅁR180) and the $-5 \mu \mathrm{m}(\mathrm{R} 5 \underline{\mathrm{P} 5})$ fractions.

\subsubsection{Core sub-sampling}

In order to control the accuracy of the XRF data for the LREE and other metals a set of 30 GT53MR180 samples from the set of core samples covering the western part of the biotite granite, i.e. kaolin pits A and B, have been selected to be analysed by ICP-MS for calibration and by QEMSCAN ${ }^{\circledR}$ for mineral characterisation. All these samples correspond to relatively-high to high grade kaolin ore, i.e. completely altered granite. The linear regression models for $\mathrm{Nb}$ and LREE prediction, obtained with process samples in Dehaine and Filippov (2015), suggest that $\mathrm{TiO}_{2}$ can be used as a "tracer" for $\mathrm{Nb}$ and LREE. Moreover, $\mathrm{TiO}_{2}$ is generally well quantified by XRF analysis. Hence, sub-samples have been selected among all the available core samples following a procedure based on their $\mathrm{TiO}_{2}$ content to have ato ensure that the obtained sub-set-representative sub-set displays the same variability as the original

dataset (Dehaine, 2016). In the end, only 26 usable samples were recovered due to technical issues (contamination, losses).

\subsection{Process samples for metal accounting and for gravity concentration testwork}

The samples used for metal accounting were collected and aggregated from daily sampling over one 
Melbur, Wheal- Martyn or Treviscoe pit. These samples are considered to be typical material from the biotite, tourmaline and topaz granite respectively. For each location, the batch of samples were composed of waste samples and a kaolin product, i.e. 5 to 6 representative samples each, depending of the mining technique (dry or hydraulic mining). Each sample is a composite, aggregated from increments collected on-site from moving streams or belts, for details about the sampling procedure see (Dehaine ${ }_{\overline{5}}(2016)$. To ensure an optimised sampling procedure in terms of frequency, sampling mode and number of increments for all the critical metals, a multivariate variographic approach has been developed to determine the required number of increments (Dehaine et al., 2016; Dehaine and Filippov, 2015b)

Process samples used for gravity concentration are screened $(-180+53 \mu \mathrm{m})$ micaceous residues corresponding to the spiral feed described in Figure 4Figure 4. Micaceous residue samples were collected from the hydrocyclone underflow tank of the full-scale plant while treating material from the same origin as the core samples, i.e. kaolin ore from pits A and B. Residue samples were collected using a by-pass to divert the whole stream into the sample collector, following the protocol described in Dehaine et al. (2016). The large micaceous residue samples collected were then screened in two successive steps, using a vibrating Roto-Sieve apparatus model RS60 (Chauvin SA, France) in order to recover the $-180+53 \mu \mathrm{m}$ size fraction of the residue for the pilot scale gravity concentration testwork. The sieves opening have been selected based on the washability of the materials (Dehaine et al., 2017), in order to improve the efficiency of the gravity concentration, but also to be able to use data from the GT53MR180 core sample products s-to characterise the feed properties of the gravity route with the objective of establishing process performance prediction models for core sample data.

\subsection{Pilot-scale gravity concentration testwork}

The influence of the LREE grade in the feed on spiral concentration efficiency has been tested with a 5-turn MKIIA Reichert spiral (Mineral Deposit Limited, Australia) using the setup described in Dehaine et al. (2017) in scavenging configuration. Operating condition are set at $0.12 \mathrm{~m}^{3} \cdot \mathrm{h}^{-1}$ wash water flowrate and $15 \%$ solid pulp density to favour recovery (Dehaine et al., 2017), concentrate splitters positions are adjusted visually for the first test but remains fixed for all the others. Spiral concentrates 
are then processed using a No.13 Wilfley laboratory shaking table (Holman-Wilfley, United-Kingdom) following the flowsheet presented in Figure 4Figure 4. The characterisation results for the shaking table presented in this paper have been obtained using the shaking table products obtained from test No.4 in Dehaine et al. (2017), which display the best separation performance.

\subsection{Particle size analysis}

Particle size analysis was performed by laser light scattering using a Helium-Neon Laser Optical System Mastersizer 3000 (Malvern instruments Ltd.) coupled with a Hydro Extended Volume (EV) sample dispersion unit. Required amounts of sample were introduced in a beaker inside the dispersion unit, equipped with a dip-in pump and a stirrer, to reach a $20 \%$ obscuration level. The particle size distributions obtained are the average of five duplicate analyses.

\subsection{Chemical analysis}

Samples were crushed and riffled alternatively in accordance with the theory of sampling to obtain representative subsamples suitable for whole rock analysis. Powdered samples (300 mg) are fused in Pt crucibles along with ultra-pure $\mathrm{LiBO}_{2}$ at $980{ }^{\circ} \mathrm{C}$ and dissolved in nitric acid. The chemical analysis of the obtained solutions were carried out by Inductively Coupled Plasma Optical-Emission Spectrometry (ICP-OES, Thermo Fischer ICap 6500) for major elements (Si, Al, Fe, Mn, Mg, Na, Ca, K, Ti, P) and Mass Spectrometry (ICP-MS, Thermo Elemental X7) for 42 trace elements, following the routine procedure of liquid chromatography ICP-MS described in Carignan et al. (2001), at the Service d'Analyses des Roches et des Minéraux (SARM-CNRS, Nancy, France).

\subsection{Mineral analysis}

For mineralogical data samples were analysed using QEMSCAN ${ }^{\circledR}$. Samples were randomly subsampledriffled, mixed with graphite powder to promote particle dispersion and reduce settling bias (Pascoe et al., 2007) and then prepared into $30 \mathrm{~mm}$ diameter epoxy resin blocks. The sample face of each block was then polished to a 1 micron finish using diamond solutions and carbon coated with 25 $\mathrm{nm}$ layer, prior to analysis. Samples were analysed using a QEMSCAN 4300 system at the Camborne 

al., 2011) using PMA mode at a resolution of 5 microns, and a target of 5000 particles per sample (see Goodall et al., 2005; Gottlieb et al., 2000; Pirrie and Rollinson, 2011, for detail on the PMA measurement mode). As the samples were well mixed and carefully prepared, the 5000 particles provided a representative sub population of each sample.Data measurement used iMeasure 4.2 SR1 and data processing used iDiscover software 4.2SR1 and 4.3. Data processing involved checking the data, customizing the database to the match samples, adding and improving SIP (database) categories as required, whilst considering the details of the technique outlined in Rollinson et al. (2011). Modal mineralogy, mineral association, average grain size, liberation data and images were output for the samples.

Additional textural observations were performed on a Hitachi FEG S4800 scanning electron microscope at the Service Commun de Microscopie Electronique et Microanalyses (SCMEM-UL, GeoRessources, Nancy, France) with an imaging voltage of $20 \mathrm{kV}$. metals.

\subsection{Methodology}

The purpose of this work is to investigate and develop preliminary geometallurgical tools for byproduct resource estimation of critical metals within the St Austell kaolin deposits with a focus on LREE. The methodology used in this study follows three main steps which aim to populate the core sample database: (1) to characterise the GT53ㅍR180 core samples through QEMSCAN analysis, to control, and calibrate if necessary, the trace element grades using duplicate ICP analyses (not presented here, see Dehaine (2016) for details), then (2) to integrate metallurgical parameters through regression models (e.g. spiral performance prediction models) applied to the GT53MR180 trace element data. 


\subsection{Comparison of the granite types}

Given the range and diversity of accessory minerals within the different granite types present at St Austell, it is likely that each granite type will have a the samedifferent potential as for by-product recovery of critical metal. In order to define the most prospective granite type for by-product metal recovery, one must compare the metal content of all the output streams of the kaolin processing route and the associated metal accounting. This is done for three distinct kaolin refining plants processing ore from weathered biotite, tourmaline or topaz granite.

Previous studies on kaolin ore originating from biotite granite have shown that metals are preconcentrated in the micaceous residue, as a consequence of the preferred separation of the heavy minerals in the hydrocyclone underflow (Dehaine and Filippov, 2015a). Comparison of the critical metal content of the output streams from the 3 investigated locations is presented in Table 2. Most of the metals, with the exception of LREE, display a similar trend than observed for the biotite granite, with an increasing grade from the coarsest waste to the micaceous residue which display the highest overall grades. The LREE grade however is slightly higher in the product stream displaying the highest LREE grade for topaz and tourmaline which means that LREE are more concentrated in the finer fractions of the clay matrix.

In terms of distribution within the outputs streams, most of the metals are distributed in the coarsest streams (stent and sand) for topaz and tourmaline granite, or the micaceous residue for biotite granite (Figure 6Figure 6). Most of the metals display a less contrasted distribution for tourmaline and topaz granite. Indeed $\mathrm{Sn}, \mathrm{Nb}$ and $\mathrm{Ta}$ are slightly more distributed in the sands then equally distributed between stent and the micaceous residue whereas the LREE show a more important proportion in the stent and product stream. This could be a consequence of the hydraulic mining processes as the stent fraction also contains fine material which sticks to the boulders or gravels.

The overall LREE and Sn content are significantly higher for the biotite granite than for the topaz and tourmaline granite. $\mathrm{Nb}$ and $\mathrm{Ta}$ content in the micaceous residue are of the same order of magnitude for the 3 locations, whereas the $\mathrm{W}$ content is three times lower for the topaz granite. This highlights This highlight strong differences in the metal content of the kaolin ore originated from different granite types. This is confirmed by the recalculated feed (clay matrix) contents which clearly shows higher LREE, Sn 
and $\mathrm{W}$ grades in the biotite granite clay matrix while $\mathrm{Nb}$-Ta grades are slightly higher for topaz granite clay matrix (Table 2). This is somehow surprising as the St Austell topaz granite, covered by the Treviscoe kaolin operations, was considered as one of the most prospective source of disseminated magmatic mineralisations from a metallogenic perspective. In addition, the high $\mathrm{Nb}$-Ta grades obtained after a two-stage gravity concentration on hydrocyclone underflow samples presented in Scott et al. (1998), suggested that micaceous residue from these areas may have a potential interest for metal recovery. This could be explained by the variations in the intensity of kaolinisation within the St Austell kaolin deposit. The kaolin ore from the topaz granite is lower grade (i.e. less weathered) than the kaolin ore from biotite granite. A less kaolinised ore (and thus less liberated metal-bearing minerals) means lower yields and larger proportions of coarse wastes.

It appears that, as a consequence the variations in the intensity of kaolinisation within the St Austell and differences in the mining technique, the micaceous residue from biotite granite, is the most prospective stream both in terms of metal content and distribution. In addition, the corresponding kaolin pits are among the largest pits located in the area associated with the more reliable extraction and processing method and the granularity of the micaceous residue doesn't require additional grinding prior to further processing.

\subsection{Core samples characterisation and validation of the geometallurgical program}

One of the primary ebjectiveobjectives of this study is to validate the core sample processing program to ensure its data is reliable and can be used for geometallurgical modelling purpose. Hence, it is necessary to compare the properties of the products obtained from the core samples treatment in the laboratory with actual process samples collected from the plant. Since kaolin processing is mainly a size classification process, the particle size distribution will be investigated, followed by the metal grades and mineralogy of the samples which are both critical for the recovery of critical metals.

\subsubsection{Particle size distribution}

Particle size distribution of the spiral feed may significantly impact the performance of the separation with the spiral concentrator. The influence of particle size on spiral performance in terms of heavy mineral recovery has been investigated by Dehaine and Filippov (2016) who observed that for the 
operating conditions at which the test have been performed, the variations of heavy minerals recovery

501 with particle size is limited and only decreases for particle sizes below $50 \mu \mathrm{m}$.

502 Particle size analysis of the GT53MR180 samples shows that the mean particle size distribution is very 503 close to the one of the spiral feeds (Figure 7Figure 6). This suggests that GT53MR180 samples are on 504 average representative, in terms of particle size, of the $-180+53 \mu \mathrm{m}$ size fraction of the micaceous

505 residue which is processed by the gravity concentration route. It can be observed that the variation in particle size distribution of the GT53MR180 $(-180+53 \mu \mathrm{m})$ fraction is relatively limited and is more important in the $-50+10 \mu \mathrm{m}$ size range. These variations are still limited compared to the high variability of the size distribution properties of the raw micaceous residue stream observed in Dehaine et al. (2016). However, these results were obtained from the raw micaceous residue, and these variations may be less visible on the screened spiral feed. In addition, the overall limited variations displayed by the core samples may also be explained by the fact that the samples set is only sourced from highly kaolinised ore and that more variations (toward the coarser fractions) should be observed with lower grade, i.e. less altered, material. Variations in particle size distribution for the spiral feed are more limited and are almost always included into the variation intervals of the GT53MR180 particle size distribution. These variations, however, do not seem to affect the performance of the spiral as illustrated in Figure 7Figure $\Theta$ by the rather small variations of spiral concentrate particle size distribution. In addition, it can be seen that the finer size ranges below $30-40 \mu \mathrm{m}$, for which the spiral feed particle size variations are more important, are poorly recovered in the spiral concentrate. This result is in agreement with the results from size-recovery curves analyses presented in Dehaine and Filippov (2016), and suggests that variations in particle sizes, at least for the finer size range is unlikely to influence the performance of the separation.

\subsubsection{Whole rock geochemistry}

The critical metals and REEs composition spectra for all GT53MR180 core samples products are presented in Figure 8Figure 8ab along with the average raw micaceous residuea high grade spiral feed sample and corresponding fresh granite trace element composition for comparison. These spectrum display clear enrichments in certain critical metals, decreasing in the order $\mathrm{Sn}, \mathrm{Nb}, \mathrm{Zr}$ and to a lesser 
extent $\mathrm{Ga}$ (Figure 8Figure 7a) as well as an enrichment in LREE, decreasing in the order Ce, La, $\mathrm{Nd}$ (Figure 8Figure $7 \mathrm{~b}$ ).

The average geochemical composition of the high-grade micaceous residuespiral feed sample shows a very similar pattern with however overall grades above around the maximum of those of the

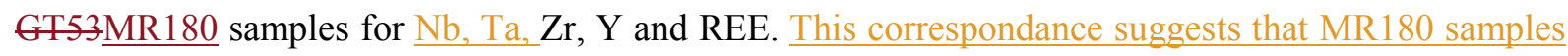
are on average representative, in terms of critical metal content, of the $-180+53 \mu \mathrm{m}$ size fraction of the micaceous residue which is processed by the gravity concentration route. This is due to the fact that these elements are known to be distributed in the finer size ranges of the micaceous residue (Dehaine and Filippov, 2015a) which are not recovered in the GT53MR180 samples $(180+53 \mu \mathrm{m})$. One sample (ref. 11069860) is highlighted in Figure 8Figure 8 due to its significantly different REE pattern, displaying an enrichment in $\mathrm{Y}$ and in Heavy Rare Earths Elements (HREEs), probably due to the presence of xenotime in that sample (Jefferies, 1985).

Comparison with geochemical data from fresh St Austell biotite granite (Simons et al., 2017, 2016) display a strong enrichment in $\mathrm{Sn}, \mathrm{Nb}$, Ta and $\mathrm{W}$ in the GT53MR180 core samples. This suggests an enrichment of these metals in the kaolinised granite whereas indium is on the contrary strongly depleted. The chondrite-normalised plot (Figure 8Figure 7c) displays a LREE enriched pattern and a strong anomaly in Eu in agreement with trace element geochemistry of the St Austell biotite granite established in previous studies (Chappell and Hine, 2006; Simons et al., 2017, 2016).

Figure 9Figure $8 \mathrm{a}$ shows a positive linear trends line between $\mathrm{Nb}$ and $\mathrm{TiO}_{2}\left(\mathrm{R}^{2}=0.70\right)$. This proportional relationship, also observed at microscopic scale and macroscopic scale in Dehaine and Filippov (2015) suggest that $\mathrm{Nb}$ is most likely associated with a $\mathrm{TiO}_{2}$-bearing mineral, i.e. rutile, ilmenorutile or ilmenite. These results may appear in contradiction with the observations of Simons et al. (2017) which suggest biotite (siderophyllite) is the main host for Nb in G3 (biotite) granites and rutile/ilmenite in G4 (tourmaline) granites. While this may indicate a change in granite type at depth, as biotite and tourmaline granites are known to be spatially associated, for example, crosscutting as sheets or forming gradational contacts (Simons et al., 2017), it may also point to the alteration of most brown micas in highly kaolinised material which are almost completely weathered by the kaolinisation process (see Mueller et al. (1999), and mineralogy section hereafter). 
Another interesting correlation is the strong correlation $\left(\mathrm{R}^{2}>0.99\right)$ between each LREE suggesting

constant relative proportions of LREE with a $\mathrm{Ce} / \mathrm{La}$ ratio of 2.27 , a Ce/Nd ratio of 2.41 , a Ce/Pr ratio of 8.67 and a Ce/Sm ratio of 12.85 in all GT53MR180 samples (Figure 9Figure 8b). These correlations and the corresponding ratios are close from the one determined by whole-rock analysis on process samples and by Energy-Dispersive X-ray Spectroscopy (EDS) analyses on monazite grains in Dehaine and Filippov (2015). This other multi-scale correspondence of element-to-element ratios from the macroscopic-deposit scale (core samples) to the microscopic scale (monazite grains) through the mesoscopic scale (process samples) is a strong evidence that monazite is the only LREE-bearing mineral in the St Austell biotite granite.

\subsubsection{Mineral characteristics}

The average modal mineralogy of the GT53 $\underline{\text { MR180 }}$ core samples obtained by QEMSCAN $^{\circledR}$ analysis is presented in Table 1 Table 1 . The mineralogy is largely dominated by quartz (48.7 wt \%), followed by fine secondary white-micas (muscovite) and tourmaline (schorl-dravite). Other minerals accounting for less than $5 \mathrm{wt} \%$ each include remaining feldspars (orthoclase, microcline) and biotite (siderophylliteannite), topaz, Ti-oxides (mostly rutile, ilmenorutile and ilmenite) and kaolinite. This is consistent with the mineralogy of the biotite granite described in Manning et al. (1996) and in agreement with the mineralogical compositions of altered biotite granite (Mueller et al., 1999). The overall modal mineralogy is very similar to the one of raw micaceous residues previously investigated, even if this size fraction seem to contain more quartz and less biotite and feldspar than typical raw residues from biotite granite (Dehaine et al., 2017; Dehaine and Filippov, 2015a).

In terms of accessory minerals hosting the critical metals, QEMSCAN ${ }^{\circledR}$ results confirmed cassiterite as the main host for $\mathrm{Sn}$, rutile-ilmenorutile as the main host for $\mathrm{Nb}$ and monazite as the host mineral for LREE. These results confirm the observations of Dehaine and Filippov (2015), even if very little wolframite is observed in the samples due the overall low $\mathrm{W}$ grades.

Mineral association data obtained by QEMSCAN $^{\circledR}$ quantifies which mineral grain is adjacent to or touches another mineral grain in a particle. Figure 10Figure 9 displays the monazite association data for the GT53MR180 samples based on QEMSCAN ${ }^{\circledR}$ results. On average, monazite grains mostly have no association (36.9\%), i.e. monazite boundary pixel occurs adjacent to a pixel of the background, which 
means that most of the monazite grains surface seem to be free. The next major associations of monazite is with tourmaline (17.3\%) and micas (14.1\%) and then by decreasing order Ti-oxides, zircon and quartz. The average monazite liberation histogram suggests it is either locked $(<10 \%$ free $)$ or liberated ( $>90 \%$ free) in the GT53 $\underline{\text { MR180 }}$ samples (Figure 11Figure 10). However, the large error bars suggest a large variability of liberation data for all core samples. This is because each sample contains a distinct population of monazite. Indeed, samples can be roughly split into two categories, the ones in which monazite is almost completely locked, representing $50 \%$ of the core samples, and the ones in which monazite is almost completely liberated (see, for example, Figure 12Figure $11 \mathrm{a}$ ), representing $47 \%$ of the core samples. When locked, monazite is often included in tourmaline (Figure 12Figure 11b), secondary muscovite (Figure 12Figure 11c) or rutile (Figure 12Figure 11d). This relates to the observations made on fresh biotite granite in which monazite is mostly included, along with zircon, in biotite and to a lesser extent in tourmaline resulting in metamictisation (Simons et al., 2016). The results obtained for the GT53MR180 samples could be linked to the kaolinisation process, which is known to affect brown micas from moderated de-ferruginisation in slightly altered granite to complete decomposition in the completely altered biotite granite whereas tourmaline remains poorly altered even for the highest degree of kaolinisation (Mueller et al., 1999). Given the highly kaolinised ore considered in this study, it is likely that monazite grains which were previously included in biotite have been progressively liberated during the decomposition of biotite whereas those included in tourmaline remained locked resulting in the above-mentioned liberation characteristics of monazite in the GT53MR180 samples. It also worth mentioning that monazite has been found to be sometimes associated with reticulated rutile (Figure 12Figure 11e). These ultrafine monazite grains display a needle shape which has the same orientation that the rutile structure. It is not clear whether these needle-shaped monazites just lay on the rutile surface or if they are actually associated with the rutile, but the presence of intergrowths and the orientation of the monazite needles seems to suggest that there is an association (Figure 12Figure 11f).

Characterisation results influence the recovery of monazite through the gravity concentration process presented in Figure 4Figure 4. The high proportions of tourmaline and micas in the GT53MR180 ($180+53 \mu \mathrm{m})$ fraction may be troublesome for the gravity concentration techniques investigated. Indeed, 
612 tourmaline has an average density close to monazite (Table 3Table 3) whereas fine phyllosilicates are

613 known to behave erratically in gravity operations. Phyllosilicates are known to cause gravity processing 614 problems, especially by increasing the slurry viscosity (Filippov et al., 2016; Sivamohan and Forssberg, 615 1985a). Monazite is mostly associated or included in tourmaline or muscovite and half of the samples 616 only contain locked monazite. Therefore only half of the LREE content of the $-180+53 \mu \mathrm{m}$ fraction of 617 the micaceous residue is potentially recoverable, which could explain some of the low recoveries 618 obtained in previous attempts to recover monazite from micaceous residues (Dehaine et al., 2017).

\subsection{Gravity concentration testwork on micaceous residue}

Large process samples were collected on-site from the micaceous residue stream of the kaolin processing plant and prepared to correspond to the $-180+53 \mu \mathrm{m}$ feed of the pilot-scale gravity concentration route described in Figure 4Figure 4. The samples were fed in a two-stage gravity concentration route, starting by a spiral concentrator in scavenging configuration to maximise the recovery. Spiral concentrates are then fed to a shaking table to increase the grade. Results from these tests work are discussed from a mineral processing perspective-process modelling and optimisation perspective in Dehaine et al. (2017) and from process mineralogy and geometallurgical perspective in the following sections.

\subsubsection{Characterisation of monazite in gravity products}

Monazite characterisation data in the different gravity concentration products obtained by QEMSCAN $^{\circledR}$ are presented in terms of mineral association and mineral liberation in Figure 13 Figure 12 and Figure 14Figure 13 respectively. It can be seen that most of the monazite recovered in the gravity concentrates is liberated even if some monazite is, to a lesser extent, locked in tourmaline or Ti-oxides. The proportion of liberated monazite decreases in the middlings whereas the proportion of locked monazite increases, in particular for the shaking table tailings. Most of the locked monazite in the middlings is associated with tourmaline which has an intermediate density $\left(3.12{\mathrm{~g} . \mathrm{cm}^{-3}}^{-3}\right.$ between those

637 of the gangue minerals $\left(2.60-2.82{\mathrm{~g} . \mathrm{cm}^{-3}}^{-3}\right)$ and the one of monazite or the other critical metal-bearing 638 minerals $\left(\geq 4.25 \mathrm{~g} \cdot \mathrm{cm}^{-3}\right)$. Other significant monazite mineral associations in the middlings include zircon, micas and Ti-oxides. The monazite lost in the gravity tailings is mostly locked, even if a non-negligible 
proportion is partially $(\leq 80 \%)$ or fully $(\leq 100 \%)$ liberated. These locked monazite grains appear to be mostly locked within tourmaline in gravity tailings but results for the shaking table suggest that a nonnegligible proportion of the monazite lost in the tailings is also associated with micas and kaolinite. concentration products (Figure 15Figure 14). It can be seen that coarse monazite tends to report to the gravity concentrates whereas ultra-fine $(-10 \mu \mathrm{m})$ monazite, either liberated or locked, reports to the tailings. This is consistent as recovery in the ultrafine particle size range is poor with most gravity processing techniques (Burt and Mills, 1984).

\subsubsection{Spiral performance prediction models}

Spiral concentration is a gravity separation technique which differentiate minerals according to particle size, density, and shape (Burt and Mills, 1984). In addition, some other important ore characteristics such as feed grade, mineral associations or liberation degree may play an important role on the separation performance (Sivamohan and Forssberg, 1985b). Most of these parameters can only be assessed by systematic mineralogical and textural analysis, for instance via QEMSCAN $^{\circledR}$. This type of analysis is time consuming and expensive and, in this study, only a few samples were characterised using this technique. However, the grade of the spiral feed is known as the feed material of the spiral concentration tests consist in the $-180+53 \mu \mathrm{m}$ fraction of the micaceous residue which corresponds to the GT53MR180 samples analysed for trace elements, including LREE. Indeed, LREE content of the GT53MR180 samples, calibrated using the ICP-MS results on duplicate samples, can be used as an estimate of the LREE feed grade for the gravity concentration circuit. A multivariate analysis applied to this LREE content and other important mineralogical properties of monazite (i.e., monazite liberation, associations and grain size) allows the identification of the most important correlations between these properties (Table 4Table 4). There is a strong positive correlation $\left(\mathrm{R}^{2}=0.83\right)$ between the average monazite grain size and degree of liberation suggesting that the coarser is the monazite the more likely it is liberated. In addition, monazite grain size and degree of liberation are both correlated to the LREE content with correlation coefficient of 0.73 and 0.65 respectively. All these properties are known to have 
preferentially report to the concentrates (Figure 14Figure 13 and Figure 15Figure 14). The fact that there are all positively correlated is an indication that the LREE feed grade could potentially be used to predict spiral concentration performance.

The influence of the LREE grade in the feed material on the spiral concentration efficiency has been tested using the spiral setup in scavenging configuration. To reflect the representativeness of the spiral feeds in terms of grade, the LREE feed grade $\left(G_{F}\right)$ is normalised using the minimum and maximum LREE contents found in the core sample database as follows:

$$
G_{F}^{*}=\frac{G_{F}-\min }{\max -\min }
$$

\section{$G_{F}^{*}$ can therefore vary between 0 and 1 , these two extreme values corresponding to the case where} $G_{F}^{*}$ equals respectively to the minimum or the maximum LREE content in the core sample database. Figure 16Figure 15 shows the influence of the normalised LREE grade $\left(G_{F}^{*}\right)$ in the feed material on the performance of spiral concentration of LREE. The results show that the normalised feed grades are well distributed over the $[0 ; 1]$ interval which suggests that they cover almost the whole range of LREE values displayed in the GT53MR180 core samples data. As expected, spiral performance is found to improve with increasing feed grade. Indeed, LREE recovery and concentrate grade increase with LREE content in the feed, with a maximum recovery and concentrate grade of $55 \%$ and $1000 \mathrm{ppm}$ respectively. However, LREE enrichment degree reaches a plateau at 4.5 for LREE normalised feed grade higher than $0.6-0.7$ ( $150 \mathrm{ppm}$ LREE). The relationship between spiral performance indexes $(y)$ and normalised feed grade shown in Figure 16Figure 15 exhibits clear trends that can be fitted by an empirical model, using the equation:

with a: Asymptote

$$
y=a+b \exp \left(c G_{F}^{*}\right)
$$

b: Scale

c: Growth rate

The parameters $a, b$ and $c$ are fitted, and have no physical meaning. However, it is expected that they would be linked to changes in mineralogy or liberation degree which consequently affects spiral performance. The values of the fitted parameters are given in Table 5Fable 5. Comparison between the 
observed and predicted values shows a good agreement with high regression coefficient values $\left(\mathrm{R}^{2}>0.9\right)$, suggesting that the models can reasonably be used to estimate spiral performance (Table 5Table 5). All performance indexes trend lines suggest that below 0.2 LREE normalised feed grade (around $60 \mathrm{ppm}$ LREE), no separation should be expected (Figure 16Figure 15). Hence, this value could be considered as the minimum grade of the GT53MR180 fraction that should be considered for LREE recovery.

The aforementioned results suggest that the regression models proposed to predict spiral performance for LREE can reasonably been applied to GT53MR180 core sample data. In addition, the range of LREE feed grade used to calibrate the models, as mentioned before, covers almost the whole range of GT53MR180 LREE grades (from 0.25 to 0.95 normalised feed grade) therefore suggesting a good representativeness of the results. Hence, prediction of spiral performance using a core sample database can be realised using the following equation (with coefficient values given in Table 5Fable 5):

$$
y=\left\{\begin{array}{lr}
a+b \exp \left(c G_{F}\right), & \text { for } G^{*}{ }_{F} \geq 0.2 \\
0 & \text { for } G^{*}{ }_{F}<0.2
\end{array}\right.
$$

\section{DISCUSSION AND CONCLUSION}

\subsection{Geometallurgical classification proposal}

This study represents the first step in the development of an integrated geometallurgical model for the optimised extraction St Austell kaolin deposits that takes into account of both-kaolin and critical metals from the St Austell deposits-rare metal graniteresources. Generally-For extraction purposesspeaking, two distinct approaches caneuld either-be used to create a spatially-based predictive geometallurgical model. The first one is based on geometallurgical testing whichtraditional approach involves small scale laboratory geometallurgical tests which aim to measure the metallurgical response of the samples in order to build predictive performance prediction-models through simulation (Bulled and Mcinnes, 2005). The-Because the metallurgical response is then-reported on an elemental basis, therefore the geometallurgical variations in the deposit-orebody are-is only based on elemental grades enly but not onrather than on mineralogical information. The second $\underline{A \text { more recent }}$ approach, based on particles, uses quantitative characterisation of particles and the minerals contained in theand particles 
characterisation data as parameters to develop athe geometallurgical program from data collection to process simulation (Lamberg, 2011). The pProcess models established are based on minerals and can use as input mineralogicatore characteristics, inc-luding mineral abundance, grain size, associations, degree of liberation, grindability, recovery potential, etc., as parametersinput for physical process models and in studies and simulationss. such asThese include mineral quantitiesabundances, minerals grainsizes-distribution, mineral associations, or liberation depending on their level of complexity (Lund et al., 2013).

The geometallurgical approach describeddepicted in this paper is, in some aspects, unconventional, and borrows aspects from both does not really fall into one of the aforementioned approaches but rather borrows elements aspects from both of them. Firstly, this study is based on a-systematic lab-scale core sample processing program which mimics the full-scale kaolin processing plant. This is an unusual approach which allows obtaininggenerates sub-samples out of core samples. Rather than performing specific metallurgical tests referring to one particular unit operation, processing of these samples which have yields similar characteristics than the corresponding similar products and residues as produced by the full-scale process., rather than performing specific metallurgical tests referring to one particular unit operation. NextIn this case, if the-elemental-basedfinal spiral performance prediction models-are only elemental based, arei.e. based on LREE grade-nly and, de consider the mineralogy of the orebody has nonetheless been taken into accountindirectly. HoweverIndeed, the fact that LREE is only hosted inby monazite is the only host mineral for the LREE, and a positive correlation is observed between that the overall the LREE grade grade is positively correlated to and mineralogical factors such as liberation or monazite grain size (Table 4Table 4), which influencefavouring the recovery. such as liberation or monazite grain size (Table 4), may-This which-explains why the process performance caneuld be predicted using only the LREE feed grade.

\subsubsection{Geometallufgiealelassifieation propesal}

In order to developalat geometallurgical ore type classification for critical metals recovery must consider; one should first consider the kaolin resources in which as-metals are regarded as a-potential 
by-products, . In other words, i.e. to be considered for metal recovery, the ore is considered for metal

recovery when it is extracted for the primary must primarily valuable for the main-commodity, i.e. kaolin, to be considered for metal recovery. When developing an ore-type classification for geometallurgical purposes it is also important to capture essential elements which are relevant in terms of metallurgical and commercial significancemeaning.

A geometallurgical ore_type classification scheme proposal for the kaolin resources is presented in Figure 17Figure 16a. It is based on the core sample data related to the R5P5 sub-samples which is an indicator of the fine kaolin product. The first classification criterion for the kaolin resources is the yield of the $\mathrm{R} 5 \mathrm{P} 5$ product, i.e. the weight ratio of the $\mathrm{R} 5 \mathrm{P} 5$ product over the feed. The R5P5 product is almost entirely composed of kaolinite plus ancillary minerals. Hence, the yield of the R5P5 product gives an indication of the future kaolin recovery, which is one of the main metallurgical response for the kaolin refining operation considered. It is closely related to the classical geological ore classification based on the degree of kaolinisation of the granite rock using visual inspection of texture preservation and feldspars alteration, as the more kaolinised is the granite the higher will be the kaolin yield once it is processed. The next classification criterion is the $\mathrm{FeO}$ content of the $\mathrm{R} 5 \mathrm{P} 5$ products, which reflect the brightness/whiteness of the kaolin product (Bertolino et al., 2010). This is a key property of the kaolin product as it drives theits commercial end-use will define to wich industry it be directed. In the end, five different ore grades are defined from the Grade I, nearly fresh to partly kaolinised granite (R5P5 yield $<10 \%$ ), to the Grade $\mathrm{V}$, fully kaolinised granite (R5P5 yield $>15 \%$ ) and low iron content $(\mathrm{FeO}<0.4 \%)$, material.

Classifying the kaolin ore in terms of its potential for critical metals recovery could be performed using the process performance prediction models. Figure 17Figure $16 \mathrm{~b}$ shows an example of the distribution of the predicted LREE recovery after the spiral concentration step for two kaolin pits by applying the empirical models presented in equations (3)(3) and (4)(4) to the corresponding GT53MR180 core sample data. One could use this chart to classify the resources in distinct recovery classes but also to delimitate the potential resources itself using the minimum feed grade suggested by the models (equations (4)(4)). 


\subsection{Application to core sample}

The application of the aforementioned geometallurgical classification schemes to an actual drill core is presented in Figure 18Figure 17. Applying the spiral performance prediction models to GT53MR180 data allows evaluation of the potential separation performance in terms of concentrate grade or recovery. This data, along with data pertaining to the R5 $\underline{\mathrm{P} 5}$ product (i.e., yield and $\mathrm{FeO}$ grade), could then be used to classify both kaolin and critical metals resources using the corresponding geometallurgical classification schemes. These domains could be used to first define the zones of interest for kaolin and then to establish if these zones are also of interest for metal recovery, therefore targeting the zones of interest for metals recovery as a by-product of kaolin.

While this approach-preliminary work is promising-and inexpensive, it would benefit from being validated by comparing the predicted performances with those obtained after processing micaceous residue samples collected when refining a block of ore for which the GT53MR180 grades are known. This may be very difficult for several technical reasons including ore traceability, contamination, large sample collection, etc. In most geometallurgical approaches, process performance prediction models are built using production data comprising a large dataset collected after months of production. Hence implementation on site of a primary concentration process (spiral concentrators for instance) seems to be the next logical step. Indeed, it would give the opportunity to collect enough data for developing similar process performance prediction models and could also allow assessing the effect of the ore variability in terms of metal grades, alteration grade and lithology (granite type) which is fundamental for the development-implementation of a proper-tactical geometallurgical modelapproach. In addition, it would allow recovering directly some primary concentrate samples for metallurgical testing, therefore removing the need for large residue samples collection. In the meantime, while no actual critical metal recovery is applied on site, this inexpensive-approach could still be used to store the residues properly according to their potential for metals recovery.

\subsection{On the commercial potential of kaolinised granites for metal recovery}

Assessing the commercial potential of kaolin residues for metal recovery is not an easy task even 
after all the work performed on this case study (Dehaine et al., 2017; Dehaine and Filippov, 2015a; Filippov et al., 2016; Scott et al., 1998). Some of the kaolinised granites mentioned in section 2.3 have been considered as potential sources for $\mathrm{Nb}, \mathrm{Ta}, \mathrm{Sn}$ or $\mathrm{W}$ and some of them are actually mined for these metals. For instance, the Yichun granite is the largest $\mathrm{Ta}, \mathrm{Nb}$ and Li raw material producer in China (Schwartz, 1992; Yichun Tantalum Co., 2005) and the Beauvoir granite is known to produce cassiterite $(800 \mathrm{~g} / \mathrm{t} \mathrm{Sn})$ and columbite (190 g/t Ta plus $120 \mathrm{~g} / \mathrm{t} \mathrm{Nb})$ as by-products of kaolin production (Negroni, 2015; Pohl, 2011). There are also some mining operations such as the Greenbushes pegmatite complex, (Australia) or the Manono-Kitotolo deposit (DRC) for which the situation is reversed and where $\mathrm{Sn}, \mathrm{Ta}$, $\mathrm{Nb}$ or Li are primary products but kaolin is regarded as a by-product (Laznicka, 2006).

From a resources point of view, the metal grades within the kaolinised rare-metal granites are low, most of them are actually well below the usual cut-off grades, but the volumes are large and the mineralisation is disseminated within the ore which is already exploited for the kaolin. The potentiality is also dependent on the granite type from which the kaolin ore originate and the variability in terms of intensity of kaolinisation as well as the extraction method. Therefore, the St Austell metal granite which is considered as one of the most prospective sources of disseminated magmatic mineralisations from a metallogenic perspective is not necessarily the most prospective in terms of by-product recovery of metals from kaolin production.

Whilst previous work on St Austell kaolin residues has demonstrated that heavy minerals can be recovered and concentrated from kaolin residues using a simple processing route with a limited number of operations, the metal grades obtained are still relatively low and further processing steps will be required before reaching an acceptable concentrate grade (Dehaine et al., 2017). The effectiveness of the heavy mineral recovery for this case study is accounted to the complexity of the considered material which is low grade, fine grained and contains high proportions of medium density minerals and clay minerals. However, high enrichment ratios (10-60) and reasonable recoveries, at least for LREE ( 60\%), have been obtained in a few separation steps without any additional grinding required.

From an environmental point of view, only benefits could arise from a potential processing of micaceous residue as the proposed processing route has a low environmental footprint with low energy consumption (gravity concentration) and environment_al-friendly chemical reagents (dispersion, 
flotation). In addition, processing the micaceous residue will result in a reduced waste production (and

831 even more if historical tailing dams are considered) and a better waste management strategy (wastes 832 sorted by size fractions).

833 From an economic point of view ${ }_{2}$ the arguments are more balanced. Indeed, the mineral concentrates obtained by beneficiating the kaolin residues is rather atypical ${ }_{2}$ with no equivalent on the market and thus there is no reference for the terms of a potential contract (Negroni, 2015). Another limitation is the application of penalties due to the presence of several metal-bearing minerals that would impair the value of the concentrate. The more restrictive issue facing LREE production is associated with the potential radioactive activity of the concentrate due to the presence of Th in monazite (Zhu et al., 2015). This means that a limitation in terms of LREE concentration should be accepted above which some special dispositions controls must be taken (dry processing, dust control, etc.). The annual income cannot be estimated but an assessment of the annual production, considering only the grade $\mathrm{V}$ ore from the sole kaolin pits investigated in this study, suggests that around $15.5 \mathrm{t} / \mathrm{y}$ LREE could be recovered in metal pre-concentrates (Dehaine, 2016). Although the current concentrate grade is low, the annual tonnage is high and total capital investment for the metal recovery process is low (Dehaine, 2016). With demand for $\mathrm{Nd}$ and $\mathrm{Ce}$ expected to grow in the future due to their use in permanent magnets (Kingsnorth, 2014b), metal recovery from kaolin residue is worth investigating for other kaolinised rare-metal granites worldwide.

\footnotetext{
Acknowledgments

This work was supported by the European FP7 project "Sustainable Technologies for Calcined Industrial Minerals in Europe" (STOICISM) [grant number NMP2-LA-2012-310645]. The authors also thank the financial support from the French National Research Agency through the 'Investissements d'avenir' national research program LabEx RESSOURCES21 (ANR-10-LABX-21-01). The authors gratefully acknowledge permission to publish by Imerys Minerals Ltd, UK, and especially S. Moradi, P. Chauhan and A. Coe for the access to the data and samples. We are also grateful to R. Joussemet, F. Diot, C. Gauthier and J-M. Fischbach from the STEVAL pilot plant team of University of Lorraine for their support during the pilot tests. B. Simons is thanked for sharing her knowledge and $\mathrm{PhD}$ data on geochemistry of Cornubian granites.
} 
860

861

862

863

864

865

866

867

868

869

870

871

872

873

874

875

876

877

878

879

880

881

882

883

884

885

886

887

888

889

890

891

892

893

894

895

896

897

898

899

900

901

902

903

904

905

906

907

908

909

910

911

912

913

914

915

916

917

918

Alderton, D.H.M., Pearce, J.A., Potts, P.J., 1980. Rare earth element mobility during granite alteration: Evidence from southwest England. Earth Planet. Sci. Lett. 49, 149-165. doi:10.1016/0012-821X(80)90157-0

Andersen, J.C.Ø., Rollinson, G.K., Snook, B., Herrington, R., Fairhurst, R.J., 2009. Use of QEMSCAN® for the characterization of $\mathrm{Ni}$-rich and $\mathrm{Ni}$-poor goethite in laterite ores. Miner. Eng. 22, 1119-1129. doi:10.1016/j.mineng.2009.03.012

Anderson, K.F.E., Wall, F., Rollinson, G.K., Moon, C.J., 2014. Quantitative mineralogical and chemical assessment of the Nkout iron ore deposit, Southern Cameroon. Ore Geol. Rev. 62, 25-39. doi:10.1016/j.oregeorev.2014.02.015

Ano, 2008. Dry mining of china clay. CFI - Ceram. Forum Int. der DKG 85, 67-69.

Anthony, J.W., Bideaux, R.A., W., K., Bladh, Nichols, M.C., 2001. Handbook of mineralogy. Mineralogical Society of America, Chantilly, VA, USA.

Belkasmi, M., Cuney, M., Pollard, P.J., Bastoul, A., 2000. Chemistry of the Ta-Nb-Sn-W oxide minerals from the Yichun rare metal granite (SE China): genetic implications and comparison with Moroccan and French Hercynian examples. Mineral. Mag. 64, 507-523. doi:10.1180/002646100549391

Bertolino, L.C., Rossi, A.M., Scorzelli, R.B., Torem, M.L., 2010. Influence of iron on kaolin whiteness: An electron paramagnetic resonance study. Appl. Clay Sci. 49, 170-175. doi:10.1016/j.clay.2010.04.022

Binnemans, K., Jones, P.T., Blanpain, B., Van Gerven, T., Pontikes, Y., 2015. Towards zero-waste valorisation of rare-earth-containing industrial process residues: a critical review. J. Clean. Prod. 99, 17-38. doi:10.1016/j.jclepro.2015.02.089

Binnemans, K., Pontikes, Y., Jones, P.T., Gerven, T. Van, Blanpain, B., Van, T., Blanpain, B., 2013. Recovery of Rare Earths From Industrial Waste Residues : a Concise Review, in: 3rd International Slag Valorisation Symposium. pp. 191-205. doi:10.1016/j.jclepro.2015.02.089

Boisvert, J.B., Rossi, M.E., Ehrig, K., Deutsch, C. V., 2013. Geometallurgical Modeling at Olympic Dam Mine, South Australia. Math. Geosci. 45, 901-925. doi:10.1007/s11004-013-9462-5

Bray, C.J., Spooner, E.T.C., 1983. Sheeted vein Sn-W mineralization and greisenization associated with economic kaolinization, Goonbarrow china clay pit, St. Austell, Cornwall, England: geologic relationships and geochronology. Econ. Geol. 78, 1064-1089. doi:10.2113/gsecongeo.78.6.1064

Breiter, K., Škoda, R., Uher, P., 2007. Nb-Ta-Ti-W-Sn-oxide minerals as indicators of a peraluminous P- and Frich granitic system evolution: Podlesí, Czech Republic. Mineral. Petrol. 91, 225-248. doi:10.1007/s00710007-0197-1

BRGM, 2011. Mineral deposits of Europe [WWW Document]. PROMINE website. URL http://promine.gtk.fi/main_mineral_deposits_of_europa.pdf (accessed 10.21.15).

British Geological Survey, 1997. Mineral Resources map for Cornwall.

Bulled, D., Mcinnes, C., 2005. Flotation plant design and production planning through geometallurgical modelling, in: Centenary of Flotation Symposium. SGS Technical Paper \#2005-03, SGS, pp. 809-814.

Burt, R.O., Mills, C., 1984. Gravity Concentration Technology, Developments in mineral processing. Elsevier Science Publishers, New York, NY.

Cabri, L.J., Wilhelmij, H.R., Eksteen, J.J., 2017. Contrasting mineralogical and processing potential of two mineralization types in the platinum group element and Ni-bearing Kapalagulu Intrusion, western Tanzania. Ore Geol. Rev. doi:10.1016/j.oregeorev.2017.04.009

Camm, G., Dominy, S., 1999. Tin Mineralization and Structure at Treliver, St. Austell, mid-Cornwall. Geosci. South West Engl. 9, 370-373.

Camm, G., Moon, C.J., 2001. Surficial geochemical signatures of tin and tungsten deposits north of the St. Austell Granite. Geosci. South West Engl. 10, 215-220.

Carignan, J., Hild, P., Mevelle, G., Morel, J., Yeghicheyan, D., 2001. Routine Analyses of Trace Elements in Geological Samples using Flow Injection and Low Pressure On-Line Liquid Chromatography Coupled to ICP-MS: A Study of Geochemical Reference Materials BR, DR-N, UB-N, AN-G and GH. Geostand. Geoanalytical Res. 25, 187-198. doi:10.1111/j.1751-908X.2001.tb00595.x

Černý, P., Blevin, P.L., Cuney, M., London, D., 2005. Granite-Related Ore Deposits, in: Hedenquist, J.W., Thompson, J.F.H., Goldfarb, R.J., Richards, J.P. (Eds.), Economic Geology 100th Anniversary Volume. Littleton, Colorado, pp. 337-370.

Chappell, B.W., Hine, R., 2006. The Cornubian Batholith: An example of magmatic fractionation on a crustal scale. Resour. Geol. 56, 203-244.

Cuney, M., Marignac, C., Weisbrod, A., 1992. The Beauvoir topaz-lepidolite albite granite (Massif Central, France): the disseminated magmatic Sn-Li-Ta-Nb-Be mineralization. Econ. Geol. 87, 1766-1794. doi:10.2113/gsecongeo.87.7.1766

Dehaine, Q., 2016. Récupération des Terres Rares ( $\mathrm{La}, \mathrm{Ce}, \mathrm{Nd})$ et métaux rares $(\mathrm{Sn}, \mathrm{Nb}, \mathrm{W})$ à partir de résidus micacés issus de la production de kaolin, $\mathrm{PhD}$ Thesis. Université de Lorraine, France.

Dehaine, Q., Filippov, L.O., 2016. Modelling heavy and gangue mineral size recovery curves using the spiral 
concentration of heavy minerals from kaolin residues. Powder Technol. 292, 331-341. doi:10.1016/j.powtec.2016.02.005

Dehaine, Q., Filippov, L.O., 2015a. Rare earth (La, Ce, Nd) and rare metals ( $\mathrm{Sn}, \mathrm{Nb}, \mathrm{W}$ ) as by-product of kaolin production, Cornwall: Part1: Selection and characterisation of the valuable stream. Miner. Eng. 76, 141153. doi:10.1016/j.mineng.2014.10.006

Dehaine, Q., Filippov, L.O., 2015b. A multivariate approach for process variograms, in: Esbensen, K.H, Wagner, C. (Ed.), TOS Forum - Proceedings of the 7th World Conference on Sampling and Blending. IM Publishers, Chichester, Bordeaux, pp. 169-174. doi:10.1255/tosf.76

Dehaine, Q., Filippov, L.O., Joussemet, R., 2017. Rare earths (La, Ce, Nd) and rare metals (Sn, Nb, W) as byproducts of kaolin production - Part 2: Gravity processing of micaceous residues. Miner. Eng. 100, 200210. doi:10.1016/j.mineng.2016.10.018

Dehaine, Q., Filippov, L.O., Royer, J.J., 2016. Comparing univariate and multivariate approaches for process variograms: A case study. Chemom. Intell. Lab. Syst. 152, 107-117. doi:10.1016/j.chemolab.2016.01.016

European Commission, 2014. Report on Critical Raw Materials for the EU, Report of the Ad hoc Working Group on defining critical raw materials. Brussels.

Filippov, L.O., Dehaine, Q., Filippova, I.V., 2016. Rare earths (La, Ce, Nd) and rare metals (Sn, Nb, W) as byproducts of kaolin production - Part 3: Processing of fines using gravity and flotation. Miner. Eng. 95, 96106. doi:10.1016/j.mineng.2016.06.004

Floyd, P.A., Exley, C.S., Styles, M.T., 1993. Igneous Rocks of South-West England. Springer Science \& Business Media, London.

Glass, H.J., 2016. Geometallurgy - Driving Innovation in the Mining Value Chain, in: Proceedings of The Third AusIMM International Geometallurgy Conference (GeoMet) 2016. AusIMM, Melbourne, pp. 15-16.

Goodall, W.R., Scales, P.J., Butcher, A.R., 2005. The use of QEMSCAN and diagnostic leaching in the characterisation of visible gold in complex ores. Miner. Eng. 18, 877-886. doi:10.1016/j.mineng.2005.01.018

Gottlieb, P., Wilkie, G., Sutherland, D., Ho-Tun, E., Suthers, S., Perera, K., Jenkins, B., Spencer, S., Butcher, A., Rayner, J., 2000. Using quantitative electron microscopy for process mineralogy applications. JOM 52, 24 25. doi:10.1007/s11837-000-0126-9

Highley, D.E., Brown, T., Harrison, D.J., Lusty, P., Cameron, D.G., Cowley, J., 2009. Mineral Planning Factsheet: kaolin. British Geological Survey, Nottingham.

Hill, P.I., Manning, D.A.C., 1987. Multiple intrusions and pervasive hydrothermal alteration in the St Austell Granite, Cornwall. Proc. Ussher Soc. 6, 447-453.

Imholte, D.D., Nguyen, R.T., Vedantam, A., Brown, M., Iyer, A., Smith, B.J., Collins, J.W., Anderson, C.G., O'Kelley, B., 2018. An assessment of U.S. rare earth availability for supporting U.S. wind energy growth targets. Energy Policy 113, 294-305. doi:10.1016/J.ENPOL.2017.11.001

Jébrak, M., Marcoux, É., 2008. Géologie des ressources minérales. Ministère des Ressources Minérales et Faune du Québec.

Jefferies, N., 1985. The distribution of the rare earth elements within the Carnmenellis Pluton, Cornwall. Mineral. Mag. 49, 495-504. doi:10.1180/minmag.1985.049.353.02

Kumari, A., Panda, R., Jha, M.K., Kumar, J.R., Lee, J.Y., 2015. Process development to recover rare earth metals from monazite mineral: A review. Miner. Eng. 79, 102-115. doi:10.1016/j.mineng.2015.05.003

Lamberg, P., 2011. Particles - the bridge between geology and metallurgy, in: Proceedings of the Conference in Mineral Engineering. Luleå, pp. 1-16.

Laznicka, P., 2006. Intracratonic Orogens, Granites, Hydrothermal Deposits, in: Giant Metallic Deposits. Springer, Berlin, Heidelberg, pp. 295-365. doi:10.1007/978-3-642-12405-1

Linnen, R., Cuney, M., 2005. Granite-related rare-element deposits and experimental constraints on Ta-Nb-W-SnZr-Hf mineralization. Rare-Element Geochemistry Miner. Depos. 45-68.

Lund, C., Lamberg, P., Lindberg, T., 2013. Practical way to quantify minerals from chemical assays at Malmberget iron ore operations - An important tool for the geometallurgical program. Miner. Eng. 49, 7-16. doi:10.1016/j.mineng.2013.04.005

Manning, D.A.C., 1996. Granites and associated igneous activity, in: The Geology Of Cornwall. Royal College of General Practitioners, pp. 120-135.

Manning, D.A.C., Exley, C.S., 1984. The origins of late-stage rocks in the St Austell granite - a re-interpretation. J. Geol. Soc. London. 141, 581-591. doi:10.1144/gsjgs.141.3.0581

Manning, D.A.C., Hill, P.I., 1990. The petrogenetic and metallogenetic significance of topaz granite from the southwest England orefield. Geol. Soc. Am. Spec. Pap. 246, 51-70. doi:10.1130/SPE246-p51

Manning, D.A.C., Hill, P.I., Howe, J.H., 1996. Primary lithological variation in the kaolinized St Austell Granite, Cornwall, England. J. Geol. Soc. London. 153, 827-838. doi:10.1144/gsjgs.153.6.0827

McDonough, W.F., Sun, S. s., 1995. The composition of the Earth. Chem. Geol. 120, 223-253. doi:10.1016/00092541(94)00140-4

McKay, N., Vann, J., Ware, W., Morley, W., Hodkiewicz, P., 2016. Strategic and Tactical Geometallurgy - a 
systematic process to add and sustain resource value, in: The Third AUSIMM International Geometallurgy Conference. AusIMM, Perth, WA, pp. 29-36.

Moon, C.J., 2010. Geochemical exploration in Cornwall and Devon: a review. Geochemistry Explor. Environ. Anal. 10, 331-351. doi:10.1144/1467-7873/09-239

Mudd, G.M., Jowitt, S.M., Werner, T.T., 2016. The world's by-product and critical metal resources part I: Uncertainties, current reporting practices, implications and grounds for optimism. Ore Geol. Rev. doi:10.1016/j.oregeorev.2016.05.001

Mueller, S., Scott, P.W., Evans, M.J., 1999. Kaolinisation, mineralisation and structures in biotite granite at Bodelva, St. Austell, Cornwall. Proc. Ussher Soc. 9, 310-317.

Müller, A., Halls, C., 2005. Rutile - the tin-tungsten host in the intrusive tourmaline breccia at Wheal Remfry, SW England, in: Mao, J., Bierlein, F. (Eds.), Mineral Deposit Research: Meeting the Global Challenge SE 115. Springer, Berlin, pp. 441-444. doi:10.1007/3-540-27946-6_115

Negroni, J., 2015. Valorisation de la cassitérite associée au gisement de kaolin de Beauvoir. Presented at Journée Mines en France 2015, Orléans, France.

Ogunleye, P.O., Garba, I., Ike, E.C., 2006. Factors contributing to enrichment and crystallization of niobium in pyrochlore in the Kaffo albite arfvedsonite granite, Ririwai Complex, Younger Granites province of Nigeria. J. African Earth Sci. 44, 372-382. doi:10.1016/j.jafrearsci.2005.12.006

Pascoe, R.D., Power, M.R., Simpson, B., 2007. QEMSCAN analysis as a tool for improved understanding of gravity separator performance. Miner. Eng. 20, 487-495. doi:10.1016/j.mineng.2006.12.012

Pirrie, D., Rollinson, G.K., 2011. Unlocking the applications of automated mineral analysis. Geol. Today 27, 226235. doi:10.1111/j.1365-2451.2011.00818.x

Pohl, W.L., 2011. Economic Geology of Metals, in: Wiley-Blackwell (Ed.), Economic Geology Principles and Practice: Metals, Minerals, Coal and Hydrocarbons - Introduction to Formation and Sustainable Exploitation of Mineral Deposits. Oxford,UK, pp. 149-284. doi:10.1002/9781444394870.ch2

Psyrillos, A., Manning, D.A.C., Burley, S.D., 1998. Geochemical constraints on kaolinization in the St Austell Granite, Cornwall, England. J. Geol. Soc. London. 155, 829-840. doi:10.1144/gsjgs.155.5.0829

Raimbault, L., Cuney, M., Azencott, C., Duthou, J.-L., Joron, J.L., 1995. Geochemical evidence for a multistage magmatic genesis of Ta-Sn-Li mineralization in the granite at Beauvoir, French Massif Central. Econ. Geol. 90, 548-576. doi:10.2113/gsecongeo.90.3.548

Rollinson, G.K., Andersen, J.C.Ø., Stickland, R.J., Boni, M., Fairhurst, R., 2011. Characterisation of non-sulphide zinc deposits using QEMSCAN®. Miner. Eng. 24, 778-787. doi:10.1016/j.mineng.2011.02.004

Schuiling, R.D., 1967. Tin belts on the continents around the Atlantic Ocean. Econ. Geol. 62, 540-550. doi:10.2113/gsecongeo.62.4.540

Schwartz, M.O., 1992. Geochemical criteria for distinguishing magmatic and metasomatic albite-enrichment in granitoids: examples from the Ta-Li granite Yichun (China) and the Sn-W deposit Tikus (Indonesia). Miner. Depos. 27, 101-108. doi:10.1007/BF00197092

Scott, P.W., Bristow, C.M., London, G.S. of, 2002. Industrial Minerals and Extractive Industry Geology: Based on Papers Presented at the Combined 36th Forum on the Geology of Industrial Minerals and 11th Extractive Industry Geology Conference, Bath, England, 7th-12th May, 2000. Geological Society of London.

Scott, P.W., Pascoe, R.D., Hart, F.W., 1998. Columbite-tantalite, rutlie and other accessory minerals from the St Austell topaz granite, Cornwall. Geosci. south-west Engl. 9, 165-170.

Sheppard, S.M.F., 1977. The Cornubian batholith, SW England: D/H and 18O/16O studies of kaolinite and other alteration minerals. J. Geol. Soc. London. 133, 573-591. doi:10.1144/gsjgs.133.6.0573

Simons, B., Andersen, J.C.Ø., Shail, R.K., Jenner, F.E., 2017. Fractionation of Li, Be, Ga, Nb, Ta, In, Sn, Sb, W and $\mathrm{Bi}$ in the peraluminous Early Permian Variscan granites of the Cornubian Batholith: Precursor processes to magmatic-hydrothermal mineralisation. Lithos 278-281, 491-512. doi:10.1016/j.lithos.2017.02.007

Simons, B., Shail, R.K., Andersen, J.C.Ø., 2016. The petrogenesis of the Early Permian Variscan granites of the Cornubian Batholith: Lower plate post-collisional peraluminous magmatism in the Rhenohercynian Zone of SW England. Lithos 260, 76-94. doi:10.1016/j.lithos.2016.05.010

Sivamohan, R., Forssberg, E., 1985a. Recovery of heavy minerals from slimes. Int. J. Miner. Process. 15, 297314. doi:10.1016/0301-7516(85)90047-X

Sivamohan, R., Forssberg, E., 1985b. Principles of spiral concentration. Int. J. Miner. Process. 15, $173-181$. doi:10.1016/0301-7516(85)90033-X

Willis-Richards, J., Jackson, N.J., 1989. Evolution of the Cornubian ore field, Southwest England; Part I, Batholith modeling and ore distribution. Econ. Geol. 84, 1078-1100.

Wilson, I.R., Halls, C., Spiro, B., 1997. A comparaison between the china clay deposits of China and Cornwall. Proc. Usher Soc. 9, 195-200.

Wilson, I.R., Jiranek, J., 1995. Kaolin deposits of the Czech Republic and some comparisons with south-west England. Proc. Usher Soc. 8, 357-362.

Yichun Tantalum Co., L., 2005. Yichun Tantalum and Niobium Mine [WWW Document]. URL http://www.yctnk.com/english/index.htm (accessed 1.23.18). 
1041 Yin, L., Pollard, P.J., Shouxi, H., Taylor, R.G., 1995. Geologic and Geochemical Characteristics of the Yichun Ta-Nb-Li Deposit, Jiangxi Province, South China. Econ. Geol. 90, 577-585. doi:10.2113/gsecongeo.90.3.577 


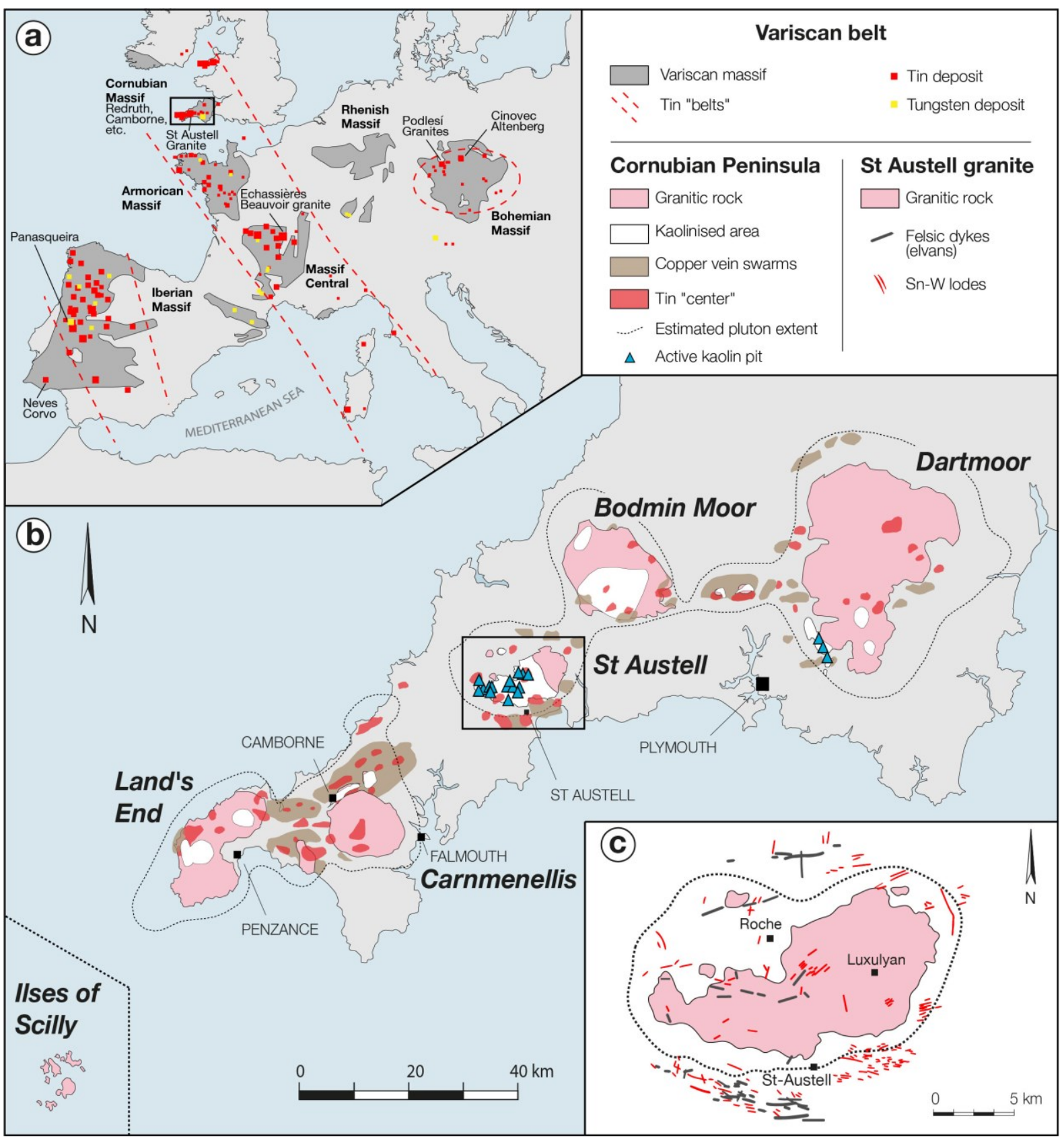

1048 Figure 1. Spatial relationship at distinct geological scales between Variscan granites and tin or tungsten deposits.

1049 (a) Tin belts in Europe and their spatial connection to the Variscan belt modified from Schuiling (1967). Main tin 1050 and tungsten deposits are from the PROMINE project (BRGM, 2011). (b) Outline geological map of South-West England peninsula showing the location of the major plutons of the Cornubian batholith, the kaolinised areas and the active kaolin pits, modified from Černý et al. (2005). (c) Distribution of the felsite dykes (elvans) and Sn-W mineral lodes around and within the St Austell rare-metal granite after Bray and Spooner (1983). 


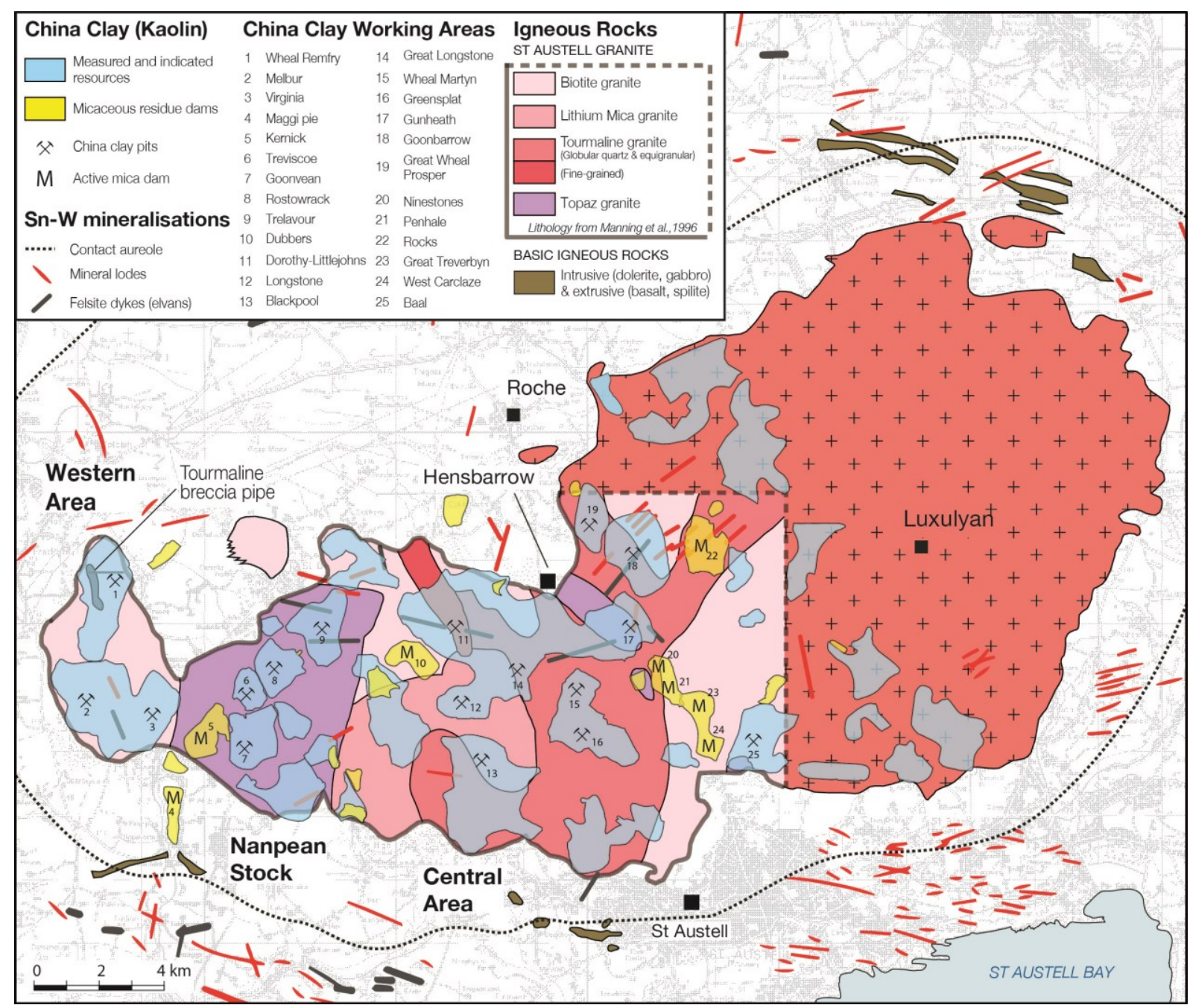

1056 Figure 2. Geological map of the St Austell granite showing the distribution of the various granite types from

1057 Manning et al. (1996), the major kaolin resources and the micaceous residue dams after British Geological Survey

1058 Geological Map Data (British Geological Survey, 1997), as well as the main Sn-W mineralisation after Bray and

1059 Spooner (1983). 

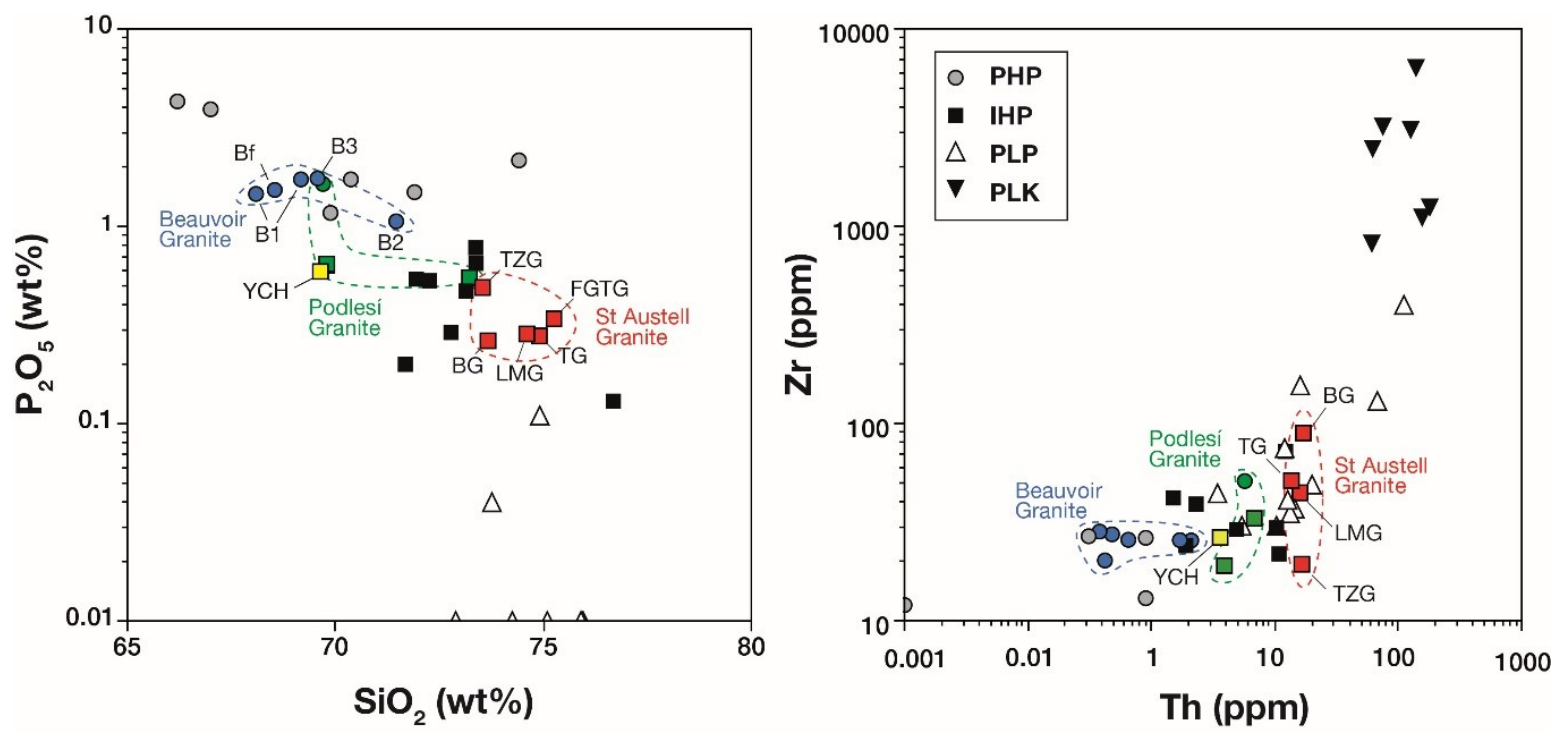

1062 Figure 3. Trace element characteristics of peraluminous high phosphorous (PHP), peraluminous intermediate phosphorous (IHP), peraluminous low phosphorous (PLP) and peralkaline granites (PLK). (a) Silica-phosphorus

1064 diagram. (b) Zirconium-thorium diagram. B series: Beauvoir granite, Massif Central; YCH: Yichun granite, Jiangxi, China. Abbreviations for St Austell granites are given in the text. Based on data from Manning et al., 1066 (1996) and the review of Raimbault et al. (1995).

1067

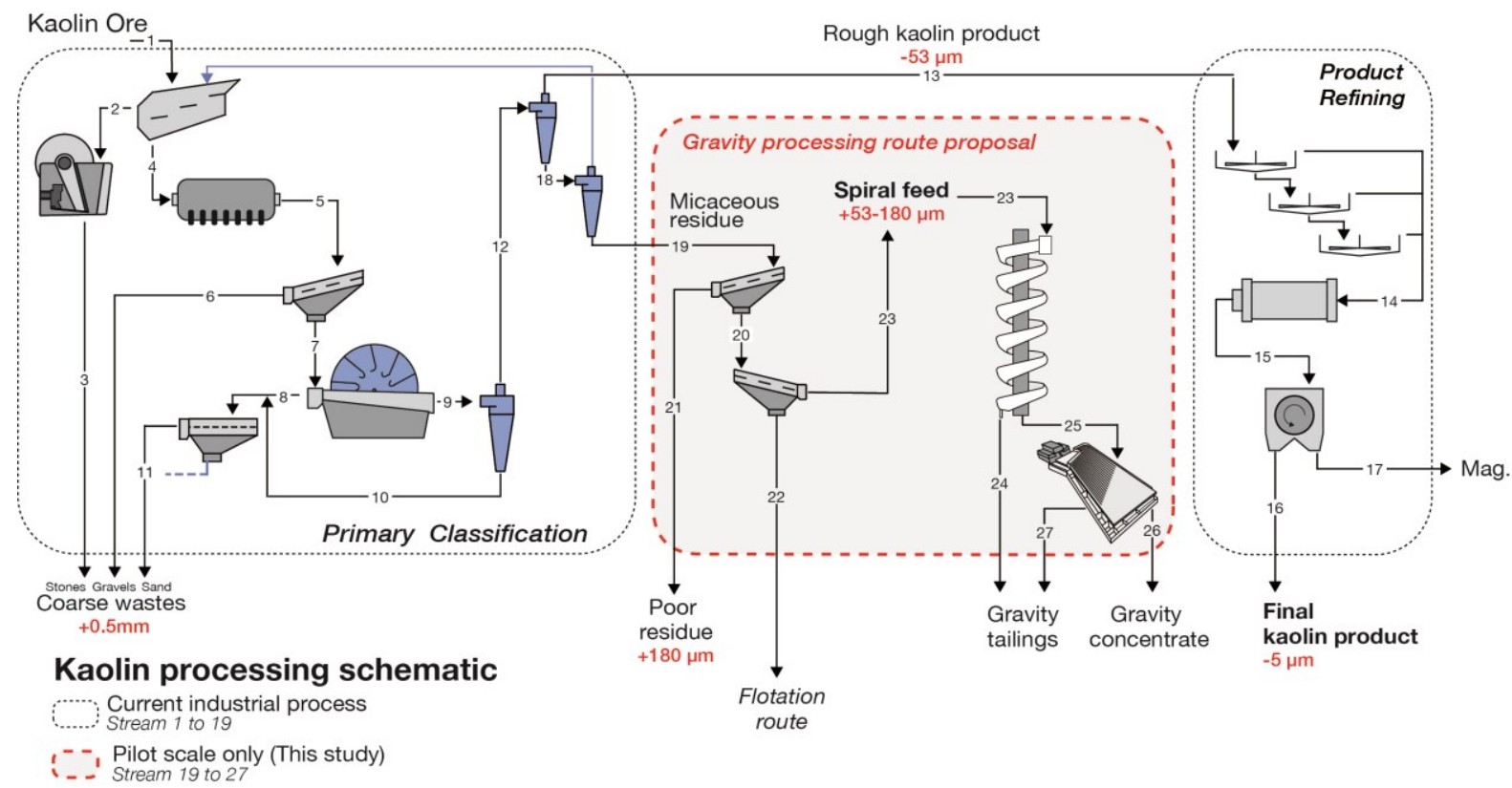

Figure 4. Simplified schematic of the kaolin ore processing and the by-product gravity processing route proposal. 


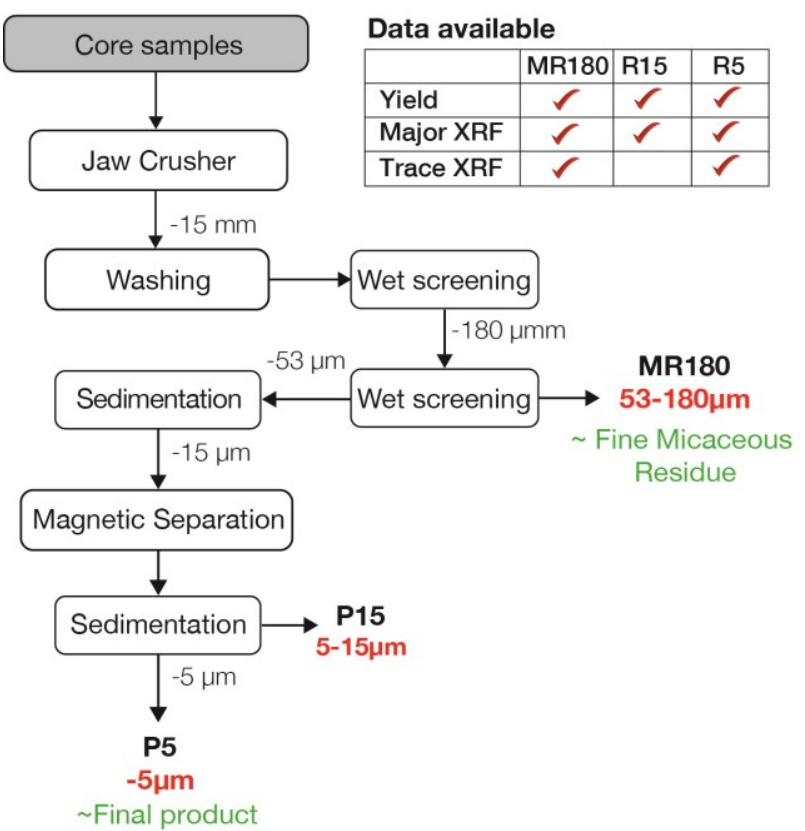

$1071 \quad$ Figure 5. Sample treatment protocol of the geometallurgical program. R5P5 and GT53MR180 products correspond to stream 16 and 23 in Figure 4Figure 4 respectively.
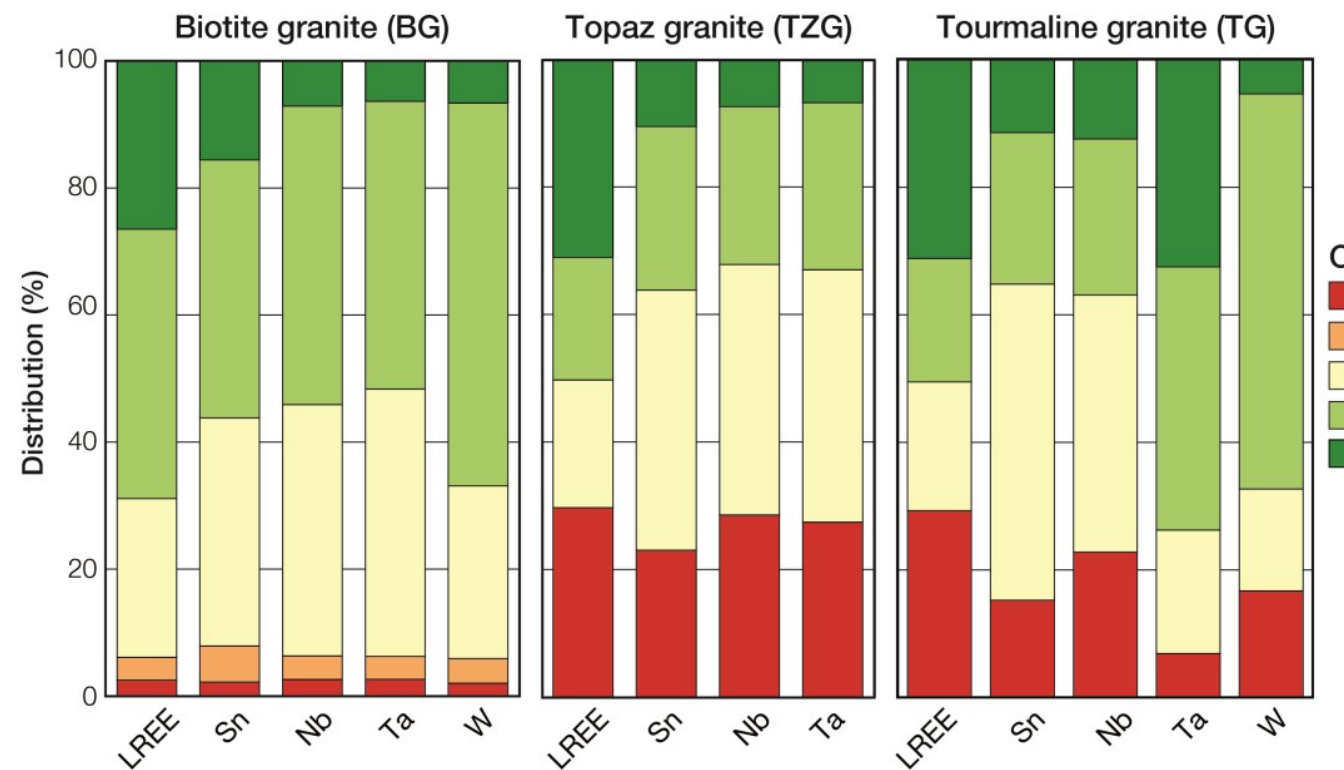

Output stream

Stones/stent

$\square$ Gravels

$\square$ Sands

Micaceous residue

$\square$ Rough product

1075 Figure 6. Metallurgical balances showing the distribution of the LREE (La, Ce, Nd) and rare metals ( $\mathrm{Sn}, \mathrm{Nb}, \mathrm{Ta}$,

1076 W) within the output streams of kaolin refining process for biotite, topaz and tourmaline granites. 


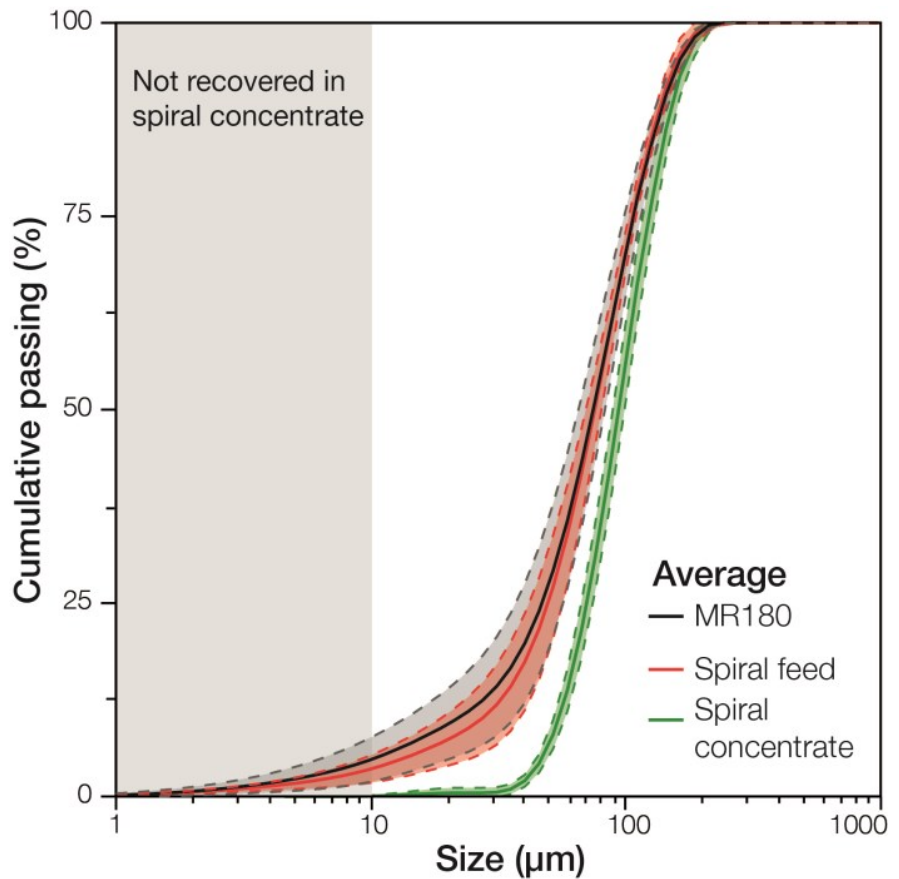

1079

Figure 76. Comparison of particle size distribution between GT53MR180 samples and corresponding process samples (spiral feed). Solid lines represent the average and dashed lines the lower and upper fence. 

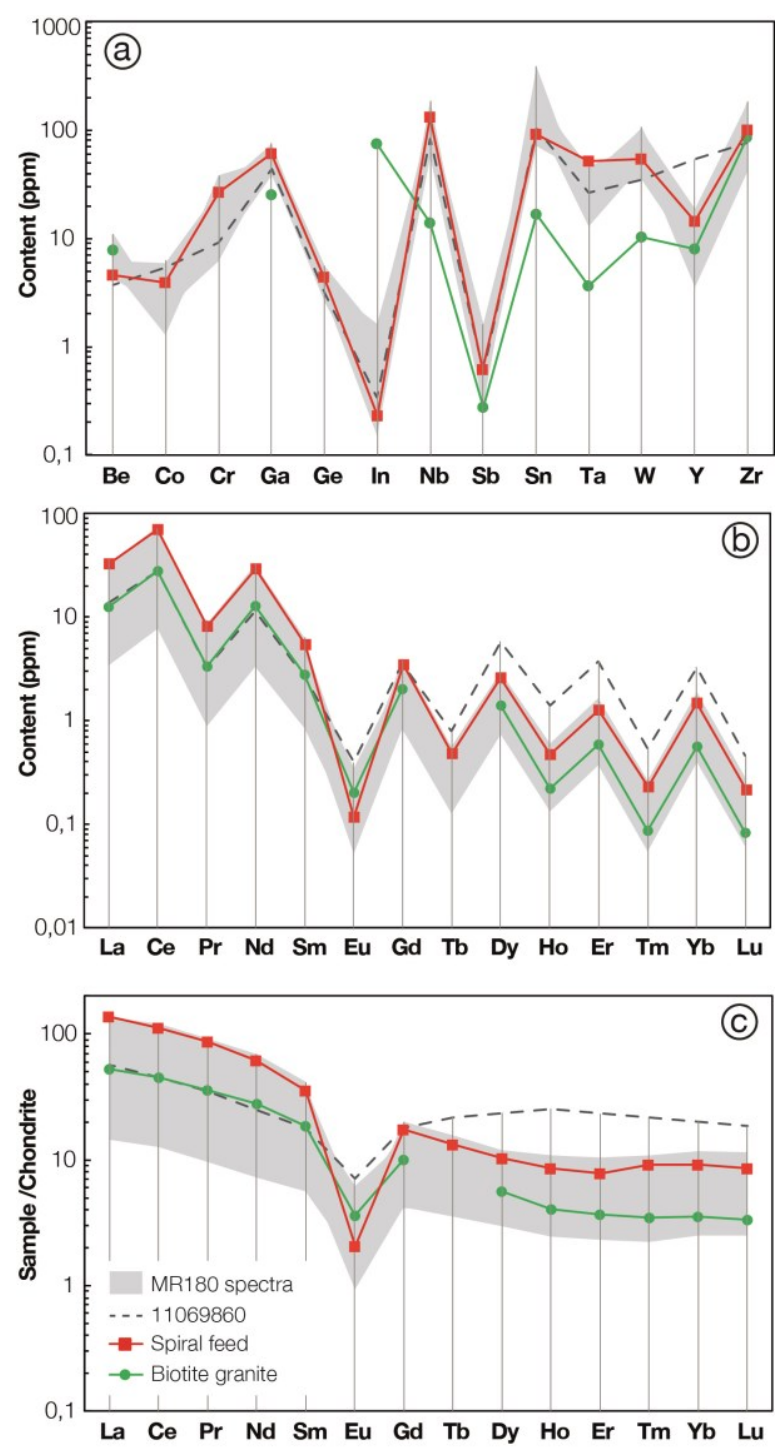

1082 Figure $\underline{8}$. Geochemical composition spectra of the GT53MR180 core samples products compared to the a raw 1083 micaceous residuespiral feed sample, obtained by ICP-MS. (a) Critical metals contents, plus Sn, Ta, Y and Zr. (b)

1084 REEs content. (c) Chondrite normalised REEs content using the values of McDonough and Sun (1995). Sample 108511069860 is highlighted due to its significantly different REE pattern, "micaceous residueSpiral feed" refers to 1086 the average of 5 micaceous reside-highest grade process samples fed to the spiral and "biotite granite" corresponds to the average REE data of 3 fresh St Austell G3 (biotite) granite from Simons et al. (2016). 

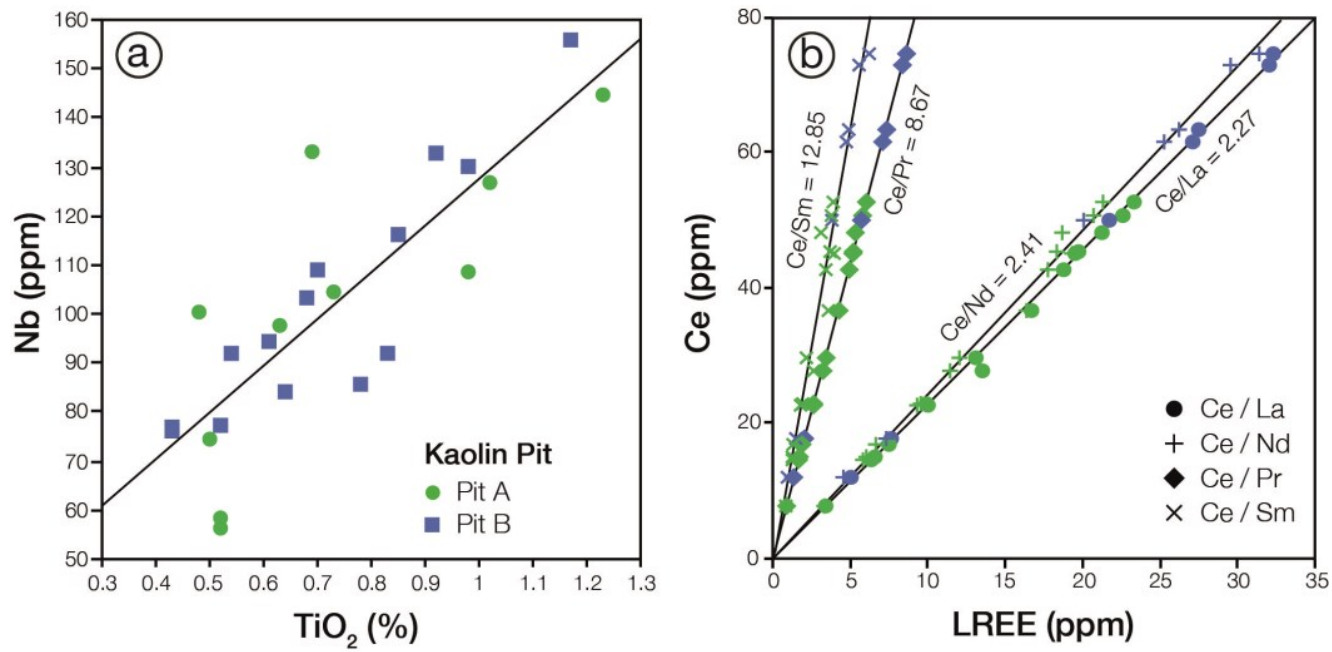

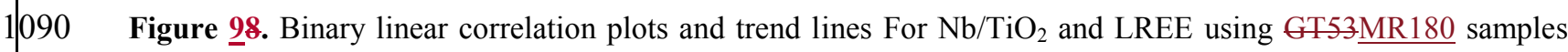
1091 ICP-MS data. (a) Good correlation $\left(\mathrm{R}^{2}=0.70\right)$ suggesting a proportional relationship between $\mathrm{TiO}_{2}$ and $\mathrm{Nb}$. (b)

1092 Strong correlations $\left(\mathrm{R}^{2}>0.99\right)$ suggesting a proportional relationship between each LREE, similar to the one observed on process samples and at the microscopic scale on monazite grains in Dehaine and Filippov (2015).

1094

1095

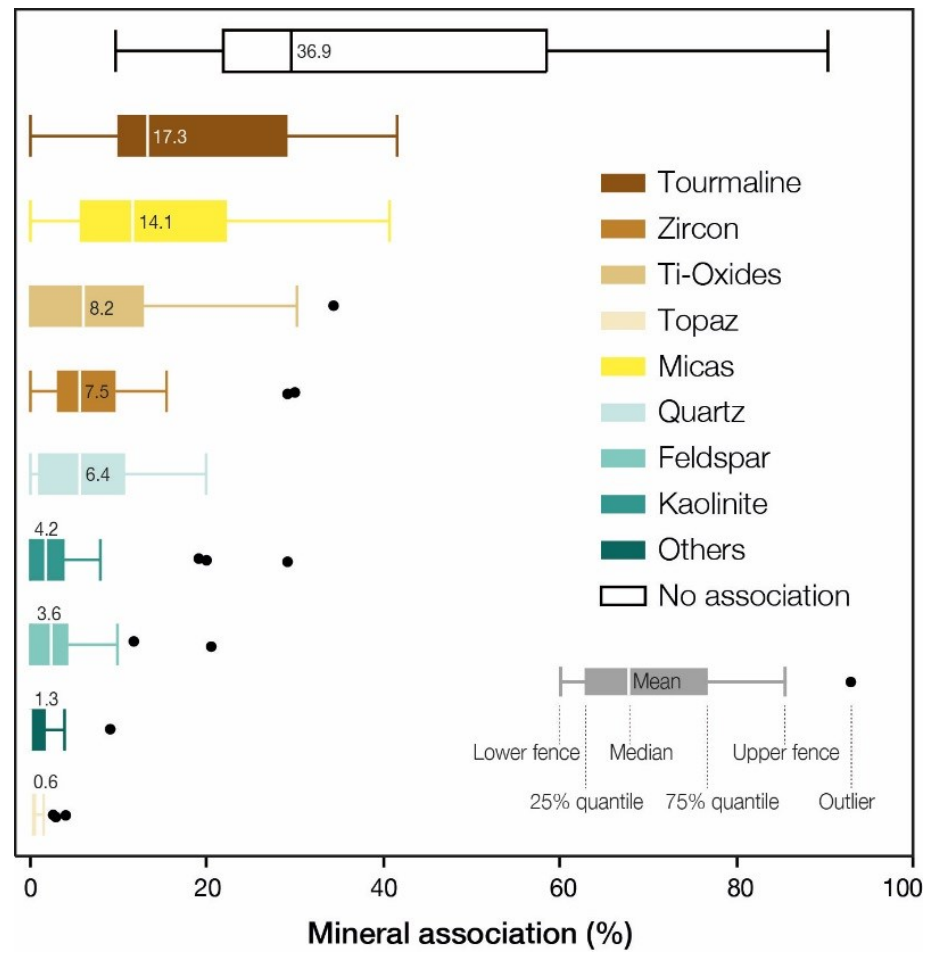

1096

Figure 109. Box-plots summarising monazite mineral association data in decreasing order for the 


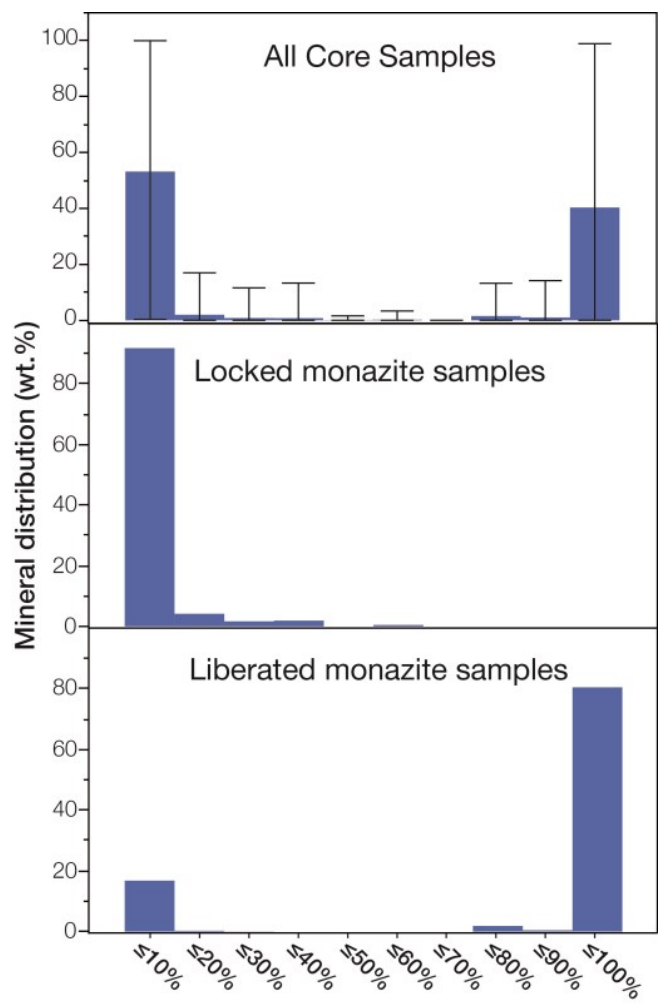

1099 Figure 1110. Average monazite liberation for all GT53ㅆR180 samples (top), for locked monazite only samples 1100 (middle) and for liberated monazite only samples (bottom). 

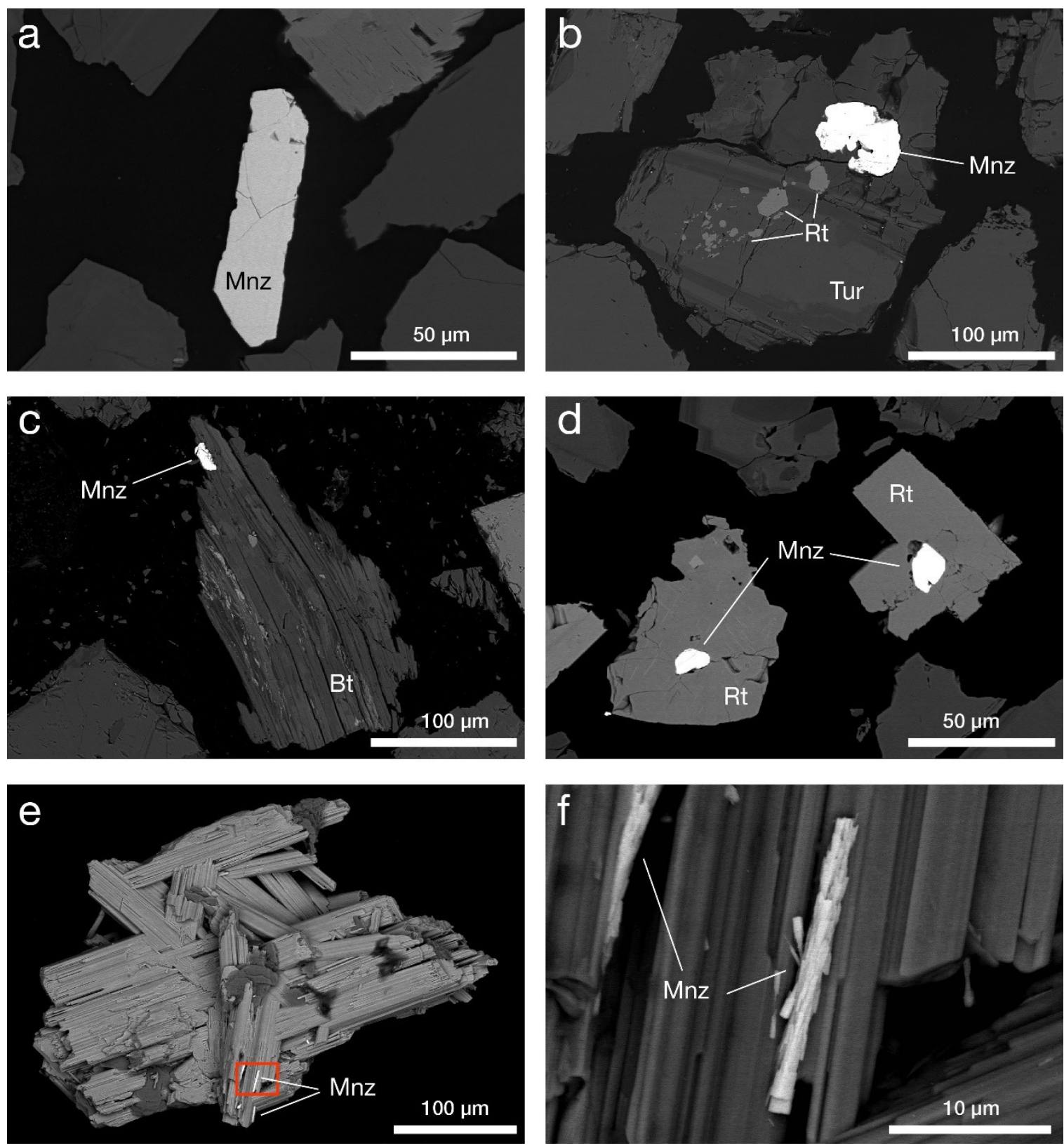

1) 102 Figure 1241. Scanning electron micrograph in back-scattered electron mode illustrating the various habitus of 1103 monazite in the micaceous residue. (a) Liberated monazite (Mnz) grain, (b) Monazite included in a zoned

1104 tourmaline (Tur) with rutile (Rt) inclusions, (c) Weathered biotite (Bt) with inclusion of monazite, (d) Monazite

1105 included in Nb-rich rutiles, (e) Monazite associated with reticulated rutile and (f) Zoomed image showing a needle-

1106 shaped monazite oriented along the rutile structure. 


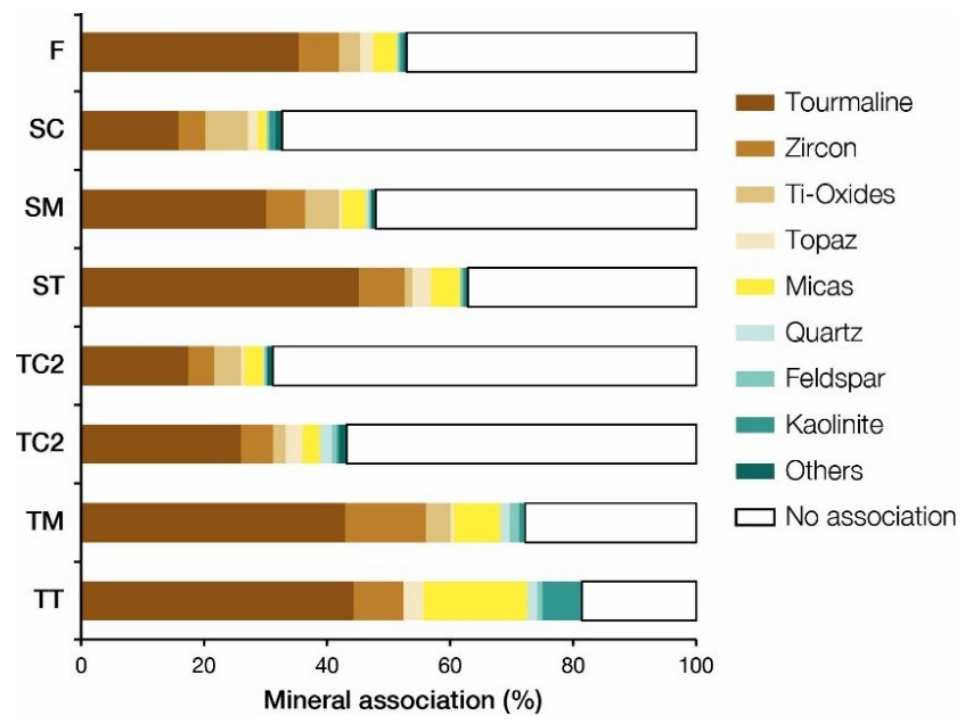

109 Figure 1312. Average mineral association for monazite in the gravity concentration products. F: Feed, SC: Spiral

1110 Concentrate, SM: Spiral Middlings, ST: Spiral Tailings, TC1: Table Concentrate 1, TC2: Table Concentrate 2,

1111 TM: Table Middlings, TT: Table Tailings.

1112

1113
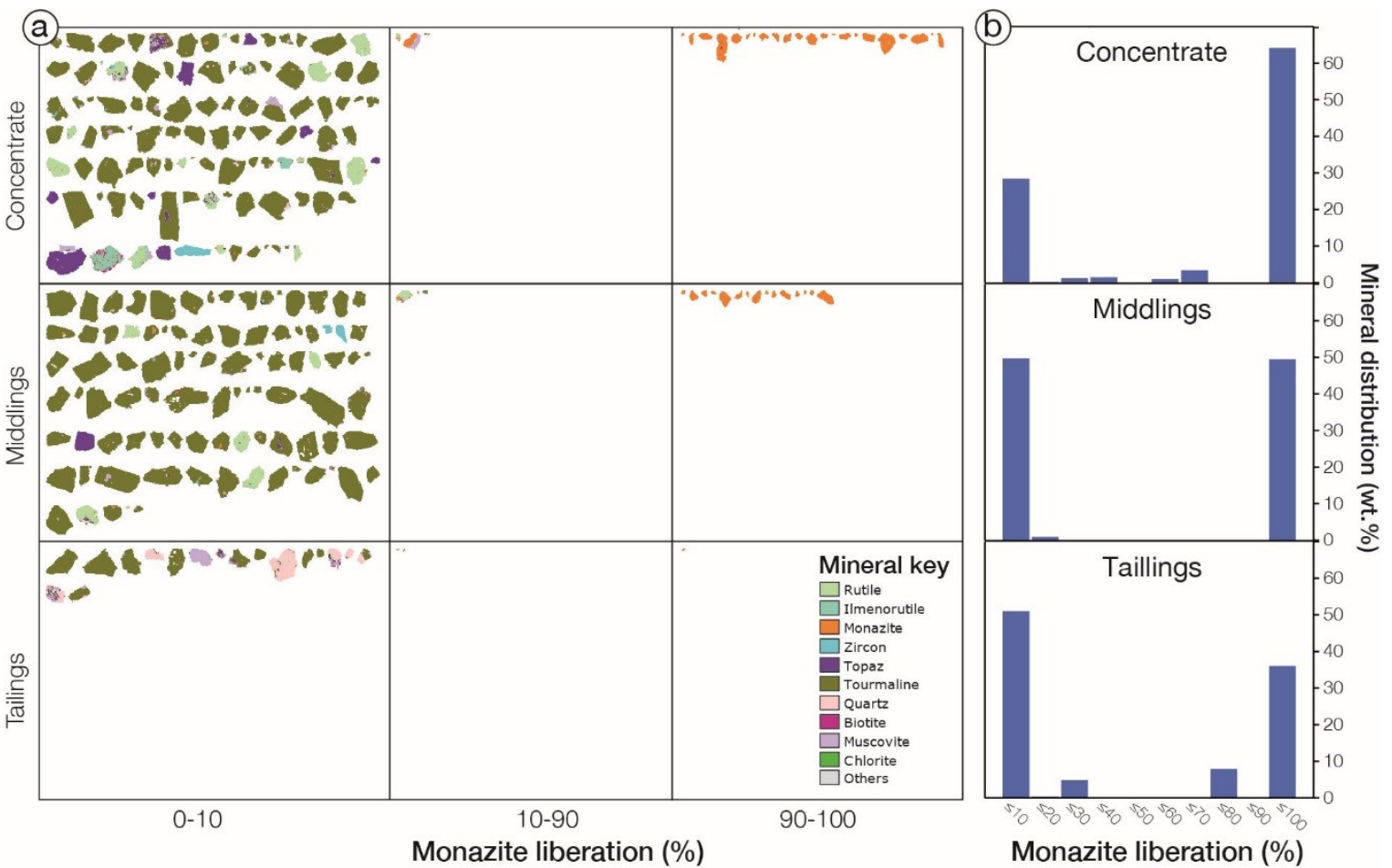

114 Figure 1413. Monazite liberation data for the gravity concentration products. (a) False colour QEMSCAN ${ }^{\circledR}$

1115 monazite liberation grid showing typical examples of spiral concentrates (top), spiral middlings (middle) or spiral

1116 tailings (bottom), only the particles containing monazite are shown. (b) Average monazite liberation data for all

1117 gravity concentration products (spiral and shaking table) including concentrates (top), middlings (middle) and

1118 tailings (bottom) 


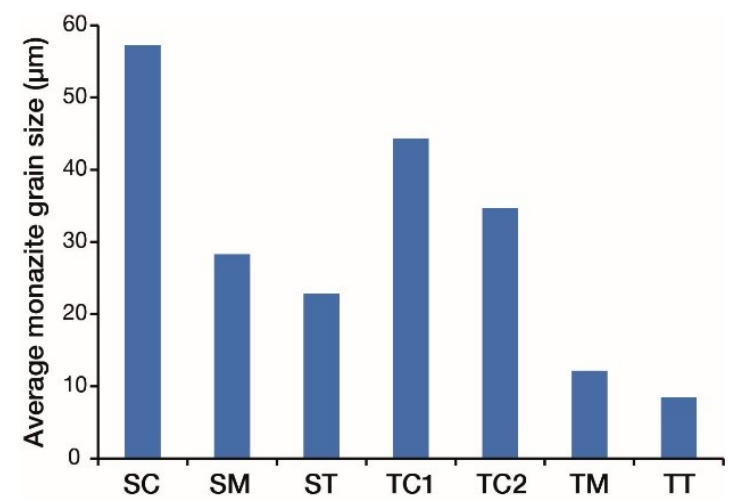

1120 Figure 15 $\mathbf{1 4}$. Average monazite grain size in the gravity concentration products. Abbreviations are given in
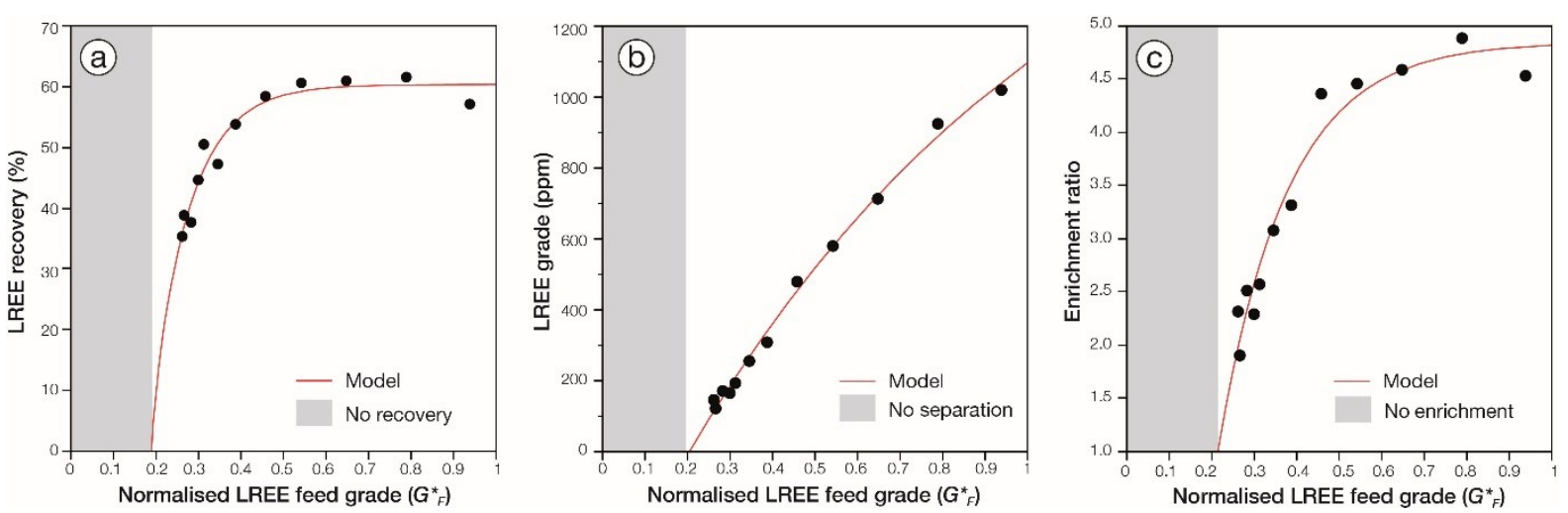

1 Figure 1615. Prediction of the performance of the rougher spiral concentration process for LREE as a function of normalised LREE feed grade. (a) LREE recovery, (b) LREE grade and (c) LREE enrichment ratio. 


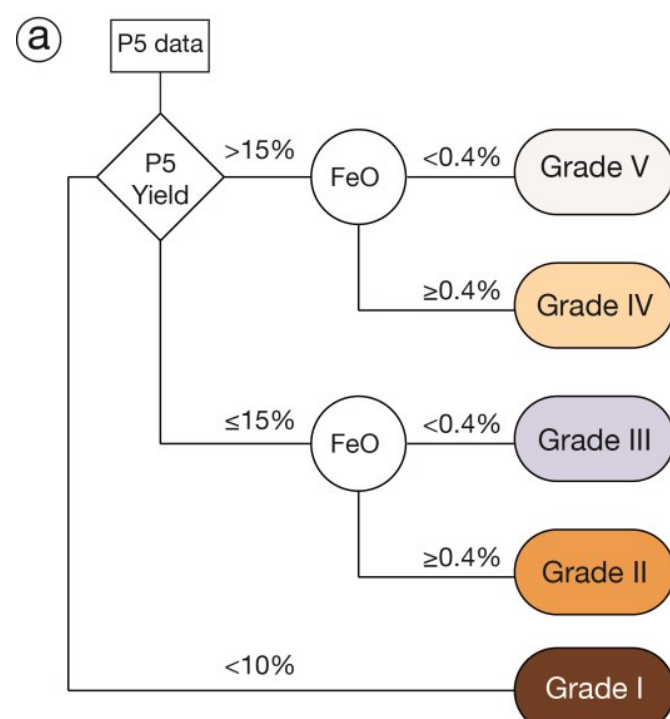

1129

1|130 Figure 1716. Proposal for geometallurgical classification schemes. (a) Geometallurgical kaolin ore-type

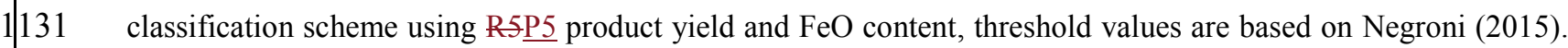

1132 (b) Histograms of LREE recovery (R) for two kaolin deposits and corresponding box-plots that could be used to

1133 classify the ore into distinct categories (i.e., $\mathrm{C} 1: \mathrm{R} \geq 60 \%, \mathrm{C} 2: 60 \%>\mathrm{R} \geq 50 \%$, etc.).

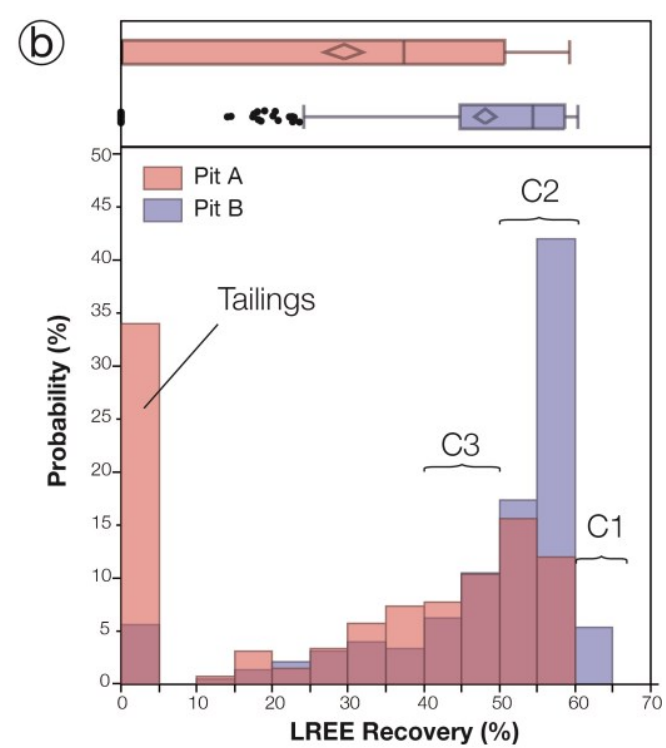

1134 


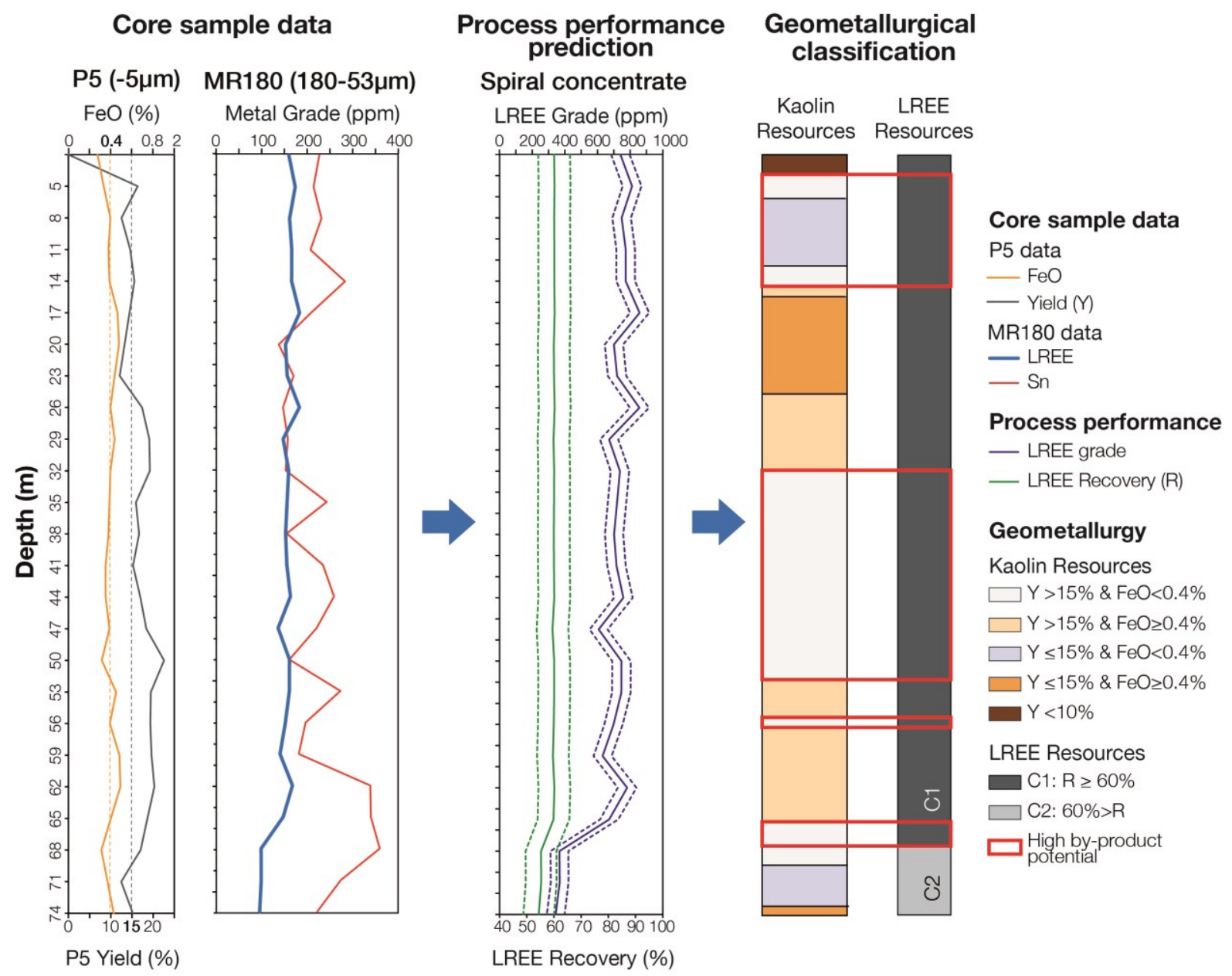

1135

Figure 1817. LREE by-product potential evaluation using process performance prediction models and geometallurgical classifications schemes applied to drill cores. (Left) Core sample data related to the final kaolin

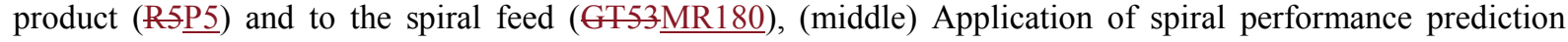
models for LREE recovery, dashed lines represent 95\% confidence intervals and (right) Geometallurgical classification of kaolin and LREE resources allowing to target the area of high potential for the recovery of LREE as by-product of kaolin. 
1144 Table 1. Mineralogy of the six major granite types of the St Austell rare-metal granite (Manning et al., 1996;

1145 Simons et al., 2016).

\begin{tabular}{|c|c|c|c|}
\hline Granite Type & Major minerals & Minor minerals & Accessory minerals \\
\hline $\begin{array}{l}\text { Biotite Granite } \\
\text { (BG) }\end{array}$ & $\begin{array}{l}\text { Quartz, K-feldspar, plagioclase, } \\
\text { biotite, muscovite }\end{array}$ & Tourmaline & $\begin{array}{l}\text { Rutile, topaz, apatite, monazite, } \\
\text { uraninite, zircon, cassiterite, cordierite }\end{array}$ \\
\hline $\begin{array}{l}\text { Lithium-mica } \\
\text { Granite (LMG) }\end{array}$ & $\begin{array}{l}\text { Quartz, K-feldspar, plagioclase } \\
\text { (albite), lithium-mica (zinnwaldite, } \\
\text { lepidolite) }\end{array}$ & $\begin{array}{l}\text { Tourmaline, } \\
\text { topaz }\end{array}$ & $\begin{array}{l}\text { Apatite, monazite, zircon, rutile, } \\
\text { fluorite }\end{array}$ \\
\hline $\begin{array}{l}\text { Tourmaline } \\
\text { Granite (TG) }\end{array}$ & $\begin{array}{l}\text { Quartz, K-feldspar, plagioclase, } \\
\text { lithium-mica (zinnwaldite) }\end{array}$ & $\begin{array}{l}\text { Tourmaline, } \\
\text { topaz }\end{array}$ & Apatite, rutile \\
\hline $\begin{array}{l}\text { Fine-grained } \\
\text { Tourmaline } \\
\text { Granite (FGTG) }\end{array}$ & $\begin{array}{l}\text { Quartz, K-feldspar, plagioclase } \\
\text { (albite), lithium-mica (zinnwaldite) }\end{array}$ & $\begin{array}{l}\text { Tourmaline, } \\
\text { topaz }\end{array}$ & $\begin{array}{l}\text { Monazite, apatite, zircon, rutile, } \\
\text { arsenopyrite, cassiterite }\end{array}$ \\
\hline $\begin{array}{l}\text { Topaz Granite } \\
\text { (TZG) }\end{array}$ & $\begin{array}{l}\text { Quartz, K-feldspar (orthoclase), } \\
\text { plagioclase, lithium-mica } \\
\text { (zinnwaldite, lepidolite), muscovite }\end{array}$ & $\begin{array}{l}\text { Topaz, fluorite, } \\
\text { tourmaline }\end{array}$ & $\begin{array}{l}\text { Apatite, amblygonite, zircon, } \\
\text { columbite-tantalite, ilmenorutile, } \\
\text { fluorite, uraninite }\end{array}$ \\
\hline
\end{tabular}

1147 Table 2. Mean LREE, Sn, Nb, Ta and $\mathrm{W}$ contents in the output streams of the kaolin plants and the estimated clay

1148 matrix content obtained by metallurgical accounting for biotite, topaz and tourmaline granite.

\begin{tabular}{lllllll}
\hline Material & $\begin{array}{l}\text { Mass Balance } \\
\text { wt.\% }\end{array}$ & $\begin{array}{l}\text { LREE } \\
\mathrm{ppm}\end{array}$ & $\begin{array}{l}\mathrm{Sn} \\
\mathrm{ppm}\end{array}$ & $\begin{array}{l}\mathrm{Nb} \\
\mathrm{ppm}\end{array}$ & $\begin{array}{l}\text { Ta } \\
\mathrm{ppm}\end{array}$ & $\begin{array}{l}\mathrm{W} \\
\mathrm{ppm}\end{array}$ \\
\hline $\begin{array}{l}\text { Biotite granite } \\
\text { Matrix }\end{array}$ & 100 & 79.1 & 68.7 & 39.9 & 11.4 & 30.8 \\
Stone & 4 & 50 & 38.3 & 26.2 & 7.6 & 15.7 \\
Gravel & 8 & 35.4 & 48.5 & 18.4 & 5.2 & 14.9 \\
Sand & 48 & 41.2 & 51.4 & 32.9 & 10 & 17.5 \\
Micaceous residue & 20 & 168.7 & 139.4 & 93.7 & 25.9 & 92.9 \\
Product & 20 & 103.7 & 53.5 & 14.2 & 3.6 & 10.3 \\
& & & & & & \\
Topaz granite & & & & & & \\
Matrix & 100 & 11.1 & 20.6 & 53.1 & 23.6 & - \\
Stent & 36 & 9 & 13.1 & 42 & 17.9 & 18 \\
Sand & 40.5 & 5.5 & 20.6 & 32.9 & 23 & - \\
Micaceous residue & 13.5 & 15.9 & 38.9 & 97.21 & 45.6 & 30.3 \\
Product & 10 & 34.3 & 21.4 & 38.84 & 15.8 & 15.5 \\
& & & & & & \\
Tourmaline granite & & & & & & \\
Matrix & 100 & 49 & 49.6 & 42.3 & 10.5 & 20.27 \\
Stent & 36 & 55 & 21 & 28 & 2 & 9.4 \\
Sand & 40.5 & 29.6 & 60.7 & 44.1 & 5 & 8 \\
Micaceous residue & 13.5 & 46.5 & 87.2 & 80.2 & 32 & 93 \\
Product & 10 & 109.9 & 56.8 & 55.1 & 34 & 10.9 \\
\hline & & & & & & \\
\hline
\end{tabular}


Table 3. Average mineralogical composition of the 26 GT53MR 180 core samples obtained by QEMSCAN ${ }^{\circledR}$ along

1151 with density data (Anthony et al., 2001).

\begin{tabular}{lccc}
\hline Mineral & Average $(\mathrm{wt} \%)$ & Std Dev. & Density $\left(\mathrm{g} . \mathrm{cm}^{-3}\right)$ \\
\hline Quartz & 48.47 & 12.16 & 2.60 \\
Feldspar (orthoclase, microcline) & 3.18 & 7.41 & 2.60 \\
Kaolinite & 1.12 & 1.03 & 2.60 \\
Muscovite & 21.99 & 10.15 & 2.82 \\
Biotite (siderophyllite-annite) & 1.72 & 1.28 & 3.09 \\
Tourmaline (schorl-dravite) & 20.97 & 10.69 & 3.12 \\
Topaz & 1.28 & 1.27 & 3.55 \\
Ti-Oxides & 1.07 & 0.48 & 4.25 \\
Zircon & 0.04 & 0.05 & 4.65 \\
Monazite & 0.04 & 0.03 & 5.15 \\
Cassiterite & 0.06 & 0.08 & 6.90 \\
Others & 0.03 & 0.21 & - \\
\hline
\end{tabular}

1152

1153

1154

Table 4. Multivariate analysis highlighting the main correlations between LREE grade and some mineralogical properties of the GT53MR180 samples ( 2 outliers deleted). Significant correlations $(\geq 0.65$ or $(-0.65 \geq)$ are highlighted in italic. Abbreviations: LREE: Calibrated LREE content/feed grade, NA: No association, A-Tour.: association with tourmaline, A-Micas: association with micas, A-Ti: association with Ti-oxides, Size: average grain size, $\%$ Locked: liberation $\leq 10 \%$ and $\%$ Liberated: liberation $\geq 90 \%$.

\begin{tabular}{lcrrrrrrr}
\hline & LREE & NA & \multicolumn{1}{c}{ A-Tour. } & \multicolumn{1}{c}{ A-Micas } & A-Ti & Size & \%Locked & \%Liberated \\
\hline LREE & $\mathbf{1 . 0 0}$ & 0.07 & -0.08 & -0.38 & 0.02 & 0.73 & -0.60 & 0.65 \\
NA & 0.07 & $\mathbf{1 . 0 0}$ & -0.62 & -0.33 & -0.15 & 0.04 & -0.08 & 0.05 \\
A-Tour. & -0.08 & -0.62 & $\mathbf{1 . 0 0}$ & -0.17 & -0.41 & 0.08 & 0.04 & 0.05 \\
A-Micas & -0.38 & -0.33 & -0.17 & $\mathbf{1 . 0 0}$ & 0.69 & -0.32 & 0.52 & -0.56 \\
A-Ti & 0.02 & -0.15 & -0.41 & 0.69 & $\mathbf{1 . 0 0}$ & 0.09 & 0.09 & -0.20 \\
Size & 0.73 & 0.04 & 0.08 & -0.32 & 0.09 & $\mathbf{1 . 0 0}$ & -0.80 & 0.83 \\
\%Locked & -0.60 & -0.08 & 0.04 & 0.52 & 0.09 & -0.80 & $\mathbf{1 . 0 0}$ & -0.96 \\
\%Liberated & 0.65 & 0.05 & 0.05 & -0.56 & -0.20 & 0.83 & -0.96 & $\mathbf{1 . 0 0}$ \\
\hline
\end{tabular}

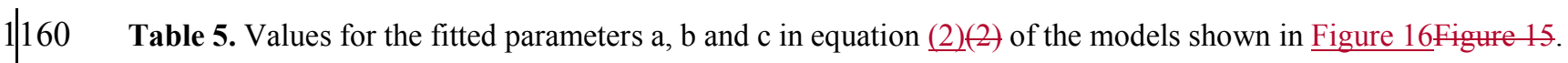

\begin{tabular}{lrrrc}
\hline Performance index\Coefficient & $\mathrm{a}$ & $\mathrm{b}$ & $\mathrm{c}$ & $\mathrm{R}^{2}$ \\
\hline Recovery & 0.60 & -4.43 & -11.06 & 0.94 \\
Grade & 1921.17 & -2386.91 & -1.06 & 0.99 \\
Enrichment & 4.85 & -14.51 & -6.19 & 0.96 \\
\hline
\end{tabular}

